WZB Discussion Paper

Petra Böhnke, Ulrich Kohler

\title{
Well-being and Inequality*
}

January 2008

Order No:

SP I 2008 - 201

ISSN 1612-3468

Research Area:

Education, Work, and Life Chances

Research Unit:

Inequality and Social

Integration

Social Science Research Center Berlin (WZB)

Reichpietschufer 50, 10785 Berlin

http://wwww.wzb.eu 
* Paper prepared as an entry for the book project "Handbook of European Societies" by Stefan Immerfall and Göran Therborn. We would like to thank our colleague Reinhard Pollak for carefully reading the piece over and over again. 


\section{Abstract}

An objective and a subjective approach to study well-being is introduced. The objective approach is particularly useful to compare the quality of life of given societies across time and space. Using the objective approach, we can identify strong differences of quality of life between European countries. In comparison to Western Europe, East European countries tend to have a rather low quality of life. Austria, the Netherlands, Sweden, Denmark and Belgium form a cluster of countries with high quality of life. The subjective approach to study well-being is useful for investigating the importance of dimensions of social inequality for people themselves. It is shown that most of the inequality dimensions traditionally analysed by social scientists affect people's subjective well-being. However, it is also shown that some of the more materialistic inequality dimensions (such as income) tend to be less important in rich societies, while certain non-materialistic dimensions (such as family) are getting more important. The subjective approach to study well-being is also used to investigate the importance of characteristics of societies for people's well-being. 


\section{Contents}

$\begin{array}{ll}\text { Introduction } & 5\end{array}$

1 An understanding of well-being $\quad 7$

1.1 Two approaches to studying well-being . . . . . . . . . . . 7

1.2 The research scope of the objective and subjective approaches . . . . . 9

2 Well-being in Europe 13

2.1 Country performance according to basic desires . . . . . . . . . . . . 13

2.2 Country performance according to subjective well-being . . . . . . . 18

3 Well-being and dimensions of social inequality 22

3.1 A primer on the regression models . . . . . . . . . . . . . . 22

3.2 Effects of social inequality on subjective well-being . . . . . . . . 23

4 Country differences in the production of well-being 32

4.1 Modernisation and the production of well-being . . . . . . . . . . . 32

4.2 The relative and absolute value of money . . . . . . . . . . . . . 34

4.3 Quality of society and its impact on well-being . . . . . . . . . 38

$\begin{array}{ll}\text { Summary } & 41\end{array}$

$\begin{array}{ll}\text { Bibliography } & 42\end{array}$ 


\section{List of Figures}

1.1 Two approaches to the study of well-being . . . . . . . . . . . . 8

2.1 Components of well-being by country . . . . . . . . . . . . . . . . . 14

2.2 Biplot of the components of well-being . . . . . . . . . . . . 18

2.3 Subjective well-being by ranked order of the Human Development Index for EQLS and ISSP . . . . . . . . . . . . . . . . . . . . . . 19

2.4 Subjective well-being by GDP based on Eurobarometer data from 1970 to $2002 \ldots \ldots \ldots \ldots \ldots$

4.1 Country specific effects of domain satisfactions on well-being by GDP per

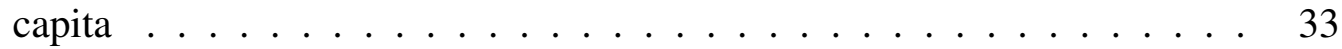

4.2 Country specific effects of dimensions of inequality on well-being by GDP per capita . . . . . . . . . . . . . . . . . 35

4.3 Country specific influence of relative income and absolute deprivation on life satisfaction by GDP per capita . . . . . . . . . . . . . 36

4.4 Average subjective evaluation of the quality of society by country . . . . 38

4.5 Country specific effects of perceived quality of society by GDP per capita $\quad 40$ 


\section{List of Tables}

3.1 Multiple linear Regression models of well-being on dimensions of inequality 24 


\section{Introduction}

Well-being is a favourable state of life. It is something desirable for every human being in the world at all times, or, as $\mathrm{Ng}$ (1996: 1) puts it, it is "the main, if not only objective of life". If a person were allowed to choose between two states of life, he or she would always choose the one which offers a higher degree of well-being. This conceptual definition, albeit fairly simple, opens the field to a rich bundle of research questions. The major questions to ask are what characteristics a state of life should consist of in order to be a favoured one, and how well-being is distributed. It is the answer to these questions and its utmost significance that has attracted scholars from many different research disciplines. Although they use different terms for well-being - "quality of life", "happiness", "satisfaction", "utility" or "living a good life"1 - the unifying questions are, what makes people happy, and why some people are less happy than others.

Interest in living conditions and the distribution of life chances in different European countries has grown considerably alongside European enlargement. The impact on wellbeing of the rapid social change experienced by most of the post-communist countries vitalises this research branch. Moreover, harmonised data, which allow a comparative perspective and comprehensive analysis of well-being in the old and new European member states, have only recently become available.

The aim of this entry is to give an overview of the results of comparative quality of life research. It is structured into three broad research topics:

1. The distribution of well-being in Europe (chapter 2): Do European countries share a typical quality of life, or are there large differences in well-being between European countries? How far can we speak of families of nations within Europe that share certain life circumstances?

2. The explanation of well-being (chapter 3): How can well-being be explained? What are the major determinants that make Europeans happy? Are common dimensions of social inequality - income, social class, gender, etc. - of importance for the individual quality of life of people?

3. Country differences in the production of well-being (chapter 4): Is there a universal model of well-being, or are there country-specific patterns in the determination of well-being? What roles do economy, politics and culture play as prevailing circumstances in shaping the ingredients of well-being?

The answer to the above- mentioned research questions must rely to a large extent on survey data. The availability of survey data therefore restricts the scope of the analyses that can be made. For most of the above questions we have used the European Quality

1 We will use the above terms interchangeably throughout this entry. 
of Life Survey (EQLS), a large-scale survey project carried out in 2003 on behalf of the "European Foundation for the Improvement of Living and Working Conditions" in 28 European Countries. The EQLS offers a unique opportunity to study the well-being of these 28 European countries. It does not, however, offer the possibility of placing these 28 European countries into the broader context of other countries such as the United States, Russia or Japan. Neither can one widen the scope of the analysis to years before 2003 when using the EQLS. As it is impossible to find directly comparable surveys for other countries and time periods, we did not attempt to give the exact comparable figures for any other country or time period. However, we provide information about how far the substantive results that we obtain for Europe also hold in other countries.

Before we go into the details of the three research topics, we would like to give a description of two conceptualisations of well-being that exist in the literature (chapter 1). We will term them the objective approach and the subjective approach. It will be shown that the two conceptualisations differ in how they measure the theoretical concept of well-being. While the objective approach uses an operational definition, the subjective approach applies a measurement hypothesis. It will also be shown that each of the two conceptualisations are suitable for answering specific research questions. While the objective approach is better suited to a dense and informative description of the aggregated quality of life of societies, the subjective approach is better suited to the identification of the causes or determinants of well-being. Hence, our chapter 2 can be seen as an application of the objective approach, while chapters 3 and 4 are applications of the subjective approach. 


\section{$1 \quad$ An understanding of well-being}

\subsection{Two approaches to studying well-being}

We can conceptually distinguish an objective and a subjective approach in the study of well-being. The objective approach is based on an operational definition of well-being. It is primarily used in studies that aim at a dense description of well-being across time and space. The Swedish "level of living" approach (Vogel 2002), the social indicator series of the OECD, and the monitoring system of the "European Foundation for the Improvement of Working and Living Conditions" (Fahey et al. 2003) are just three examples of this approach. In contrast, the subjective approach sets up a measurement model by using a subjective indicator for the latent construct of "well-being". This approach is primarily used in studies that investigate the causes and correlates of well-being. It has been used by psychologists and sociologists, and has also attracted economists. We will describe the two approaches and their implications in some detail in this section.

Figure 1.1 illustrates the two approaches to well-being by means of path diagrams. In such path diagrams, circles are used to display theoretical concepts and rectangles are used to display observed indicators. Arrows are used to show causal connections between concepts and indicators. The arrow starts from the concept/indicator that has a causal effect, and the arrowhead points to the concept/indicator that is influenced. The figure highlights the similarities and differences between the two concepts of well-being.

Well-being is at the heart of both approaches and both of them regard well-being as a favourable state of life, as something desirable in itself. A second similarity is that both approaches regard well-being as a consequence of several factors. In figure 1.1 we have denoted these factors X1 and X2, but it should be understood that X1 and X2 represent a whole set of factors like, for example, income, quality of accommodation, security, health, etc. The question of what these "Xs" are is an important topic for researchers of well-being. Some of the more prominent factors that are said to influence well-being are dimensions of social inequality; we are going to deal with them in some detail later on. However, for now it is enough to say that scholars agree that there are many such factors; in this sense well-being is a multi-dimensional concept.

The major difference between the two approaches lies in the treatment of "subjective" well-being. For the sake of simplicity let us assume that subjective well-being comprises observed values taken from survey questions such as life satisfaction or happiness. In the subjective approach an arrow goes from well-being to subjective well-being. This represents the hypothesis that well-being influences the answer to questions about life satisfaction and happiness so that high well-being typically results in high subjective wellbeing. Hence, subjective well-being is treated as an indicator of well-being. The Xs, on the other hand, are treated as causes of well-being; in other words factors such as high income, being in good health and having a nice dwelling influence well-being. As a consequence, subjective well-being is also linked to these commodities, as they effect well-being, which 


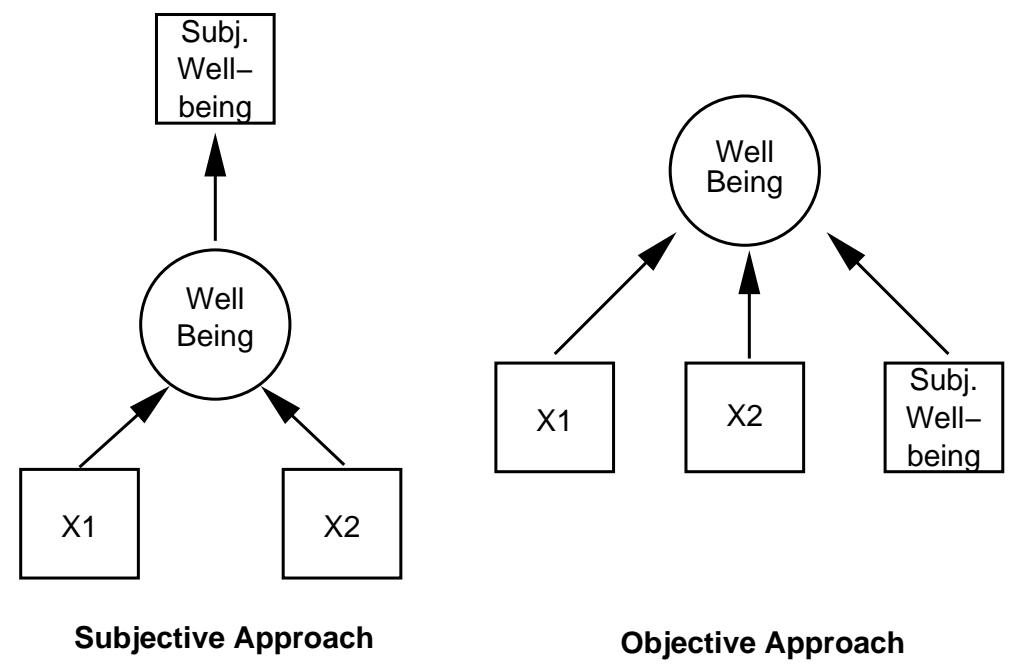

Figure 1.1: Two approaches to the study of well-being

in turn effects the observed values of subjective well-being. Conceptually it is therefore impossible to observe a change in one of the Xs without observing a corresponding change in subjective well-being. If we do not observe such a correlation, one (or more) of the causal hypothesis represented by the arrows on the left hand side of figure 1.1 must be false. Either a specific X does not really influence well-being, or subjective well-being is not a good indicator of well-being. Therefore, the advantage of the subjective approach is that it offers a way to select the set of commodities: The important ones are those which strongly effect subjective well-being.

The objective approach does not treat subjective well-being as an observed indicator of well-being. Instead, subjective well-being appears as yet another factor that influences well-being. Note the difference to the subjective approach in terms of expected correlations: the path diagram displays no causal link between the commodities (represented by X1 and X2) and subjective well-being. Instead, subjective well-being influences wellbeing just like the other commodities. This means that regardless of how many goods or commodities a person possesses, a low subjective well-being will always reduce his or her individual well-being to some extent. On the other hand, even for individuals with a very low subjective well-being, one would state that they have a high quality of life if they rank high on the causes for well-being. Overall it is conceptually not expected that any of the commodities and subjective well-being correlate; however the possibility is not excluded.

A final point concerning the objective approach shown in figure 1.1 is that it does not contain a measurement model for well-being. A measurement model should treat observed indicators - like income, health, etc. - as a consequence of the construct that is measured (well-being). Treated that way, one would claim that what people earn and how healthy they are depend on their well-being, which is clearly not a convincing hypothesis. It is much more convincing to state that income, health etc. influence well-being than the other way around. Unfortunately this latter hypothesis cannot be analysed without an explicit measurement of well-being, which in turn requires a measurement model. The only way 
out of this vicious circle is to apply an operational definition for measuring well-being. One can define well-being as a mixture of a specific set of indicators. Well-being then simply is the proposed mixture of indicators. Such a definition cannot be true or false. Instead it is something that one has to agree upon. The objective approach must therefore start with agreement between researchers on the set of indicators for the measurement of well-being. If the researchers don't agree, an external criterium for deciding who is right is missing. In practise there is no broad consensus on the indicators to be included in the measurement of well-being. There is not even any agreement on whether subjective well-being should be included into the definition of well-being or not. Some include them (Fahey et al. 2003); others do not (Vogel 2002; Atkinson et al. 2002). But regardless of whether subjective well-being is included, it is always the researcher who decides what indicators well-being consists of. Hence, we call this approach the objective approach, because the production function for happiness.

As already stated, the two concepts of well-being are typically connected to different research questions. We will describe them in some detail in the next section.

\subsection{The research scope of the objective and subjective approaches}

The objective approach to analysing well-being is commonly used for comparisons of well-being between countries or between different time-points. Describing the quality of life in different societies in terms of subjective well being is often considered as too narrow. The subjective approach is typically used for research on the causes of wellbeing. To investigate the causes of well-being, a measurement of well-being is needed that is conceptually independent of its causes. Subjective well-being is therefore taken as an indicator that reveals well-being as well as possible. In what follows we give an overview of the research scope of the two approaches with information about typically related research questions, hypothesis and measurement issues.

\section{The objective approach}

How does well-being develop over time? This has always been one of the guiding questions of the analyses of well-being using the objective approach. People like to know how the overall quality of life has developed over time, and the broad view on well-being integrated in the objective approach is capable of providing a much more comprehensive picture than the narrow subjective approach. The question itself is often linked to some sort of modernisation theory that expects an increase of well-being in quantity and quality over time. In addition, the question of whether there are different levels of well-being in different countries is important in order to be able to compare country performances internationally. This descriptive approach is often expanded with the question, of whether the dimensions of well-being are interrelated. Conceptually the factors that define well-being in the objective approach are not causally linked together. Whether they are correlated or not is therefore an empirical question. If they are strongly correlated, one will often observe what has been called "multiple deprivation", which means a low status in more 
than one dimension of quality of life. The correlation between the dimensions of wellbeing might also vary over time or between countries, which leads to another dimension of describing societies' well-being across time and space.

With regard to measurement issues, the objective approach tries to set up a list of goods that are necessary for a good life. Such lists might contain goods like health, working conditions, income, housing, safety, integration etc. A survey then finds out whether and how much of these goods each respondent has been able to achieve. The objective approach measures well-being by observing whether individuals have control over certain resources or not. This raises the obvious question of what the most important goods that should be observed are. In an overview of conceptualisations of well-being, Fahey et al. (2003: 5360 ) conclude that it is commonly agreed to refer to the domains health, integration in the labour market, education, income and security. There is also a clear majority for including the domains housing, family, social relationships and the environment. However there is much disagreement about the inclusion of some other living conditions. The Swedish tradition, for example, includes political resources, German social reports refer to leisure and media consumption, and the New Zealand social report uses domains covering human rights, culture and identity.

However, the highest level of disagreement about how to measure well-being is about the issue of the inclusion of subjective well-being. Approaches that do not include subjective well-being in the conceptualisation of well-being are the Swedish "level of living" approach (Erikson 1993; Vogel 2002), the OECD system of social indicators and the "Laeken indicators" adopted by the European Council to measure social inclusion (Atkinson et al. 2002). The divergent view, which includes subjective well-being, is represented by official social reporting in Germany (Zapf 1984; Noll 1997), and by the influential work of Erik Allardt (1993). This approach was also adopted by the EU-wide monitoring system of the "European Foundation for the Improvement of Working and Living Conditions" (Fahey et al. 2003). ${ }^{1}$

In practice, the conceptual difference between the externally observable "objective" living conditions and the externally unobservable subjective well-being often diminishes. Indicators taken to represent objective living conditions are often derived from respondents' subjective evaluations of these living conditions. It is not uncommon for surveys to ask questions about the respondents' evaluation of, for example, their own health. Such questions can be either regarded as an indicator of the objective health condition or as a dimension of the subjective satisfaction with it.

\section{The subjective approach}

In the subjective approach, the theoretical concept of "well-being" is measured by people's subjective evaluations of their own lives. Therefore the subjective approach leaves

1 Subjective well-being is also sometimes considered as a multidimensional concept in itself. Diener und Suh (1997), for example, state that it consists of three interrelated components: life satisfaction, pleasant effects and unpleasant effects. 'Effects' refer to moods and emotions, whereas life satisfaction is rather cognitive (Diener und Suh 1997: 200). Which dimension of subjective well-being should be part of the conceptualisation of well-being is therefore always questionable. 
it completely up to individuals as to what goods they desire. Because the subjective approach has this measurement model - and given that the measurement model is true - it is possible to analyse the relationship between the acquisition of goods and well-being. Such analyses can be used to empirically answer some of the questions passionately debated under the objective approach: The core question of the objective approach is to agree upon a list of goods that are necessary for a good life. As soon as one accepts the possibility of measuring the degree of well-being independently of a list of goods, this question can be answered empirically: People's desires, wants and needs are what increase subjective well-being. Whether desires are universal or not then also becomes an empirical question: People's desires are universal as long as the same set of goods affects subjective well-being in a similar way in all societies; the cultural dependency of people's desires is reflected in goods that affect subjective well-being differently under various social settings. Another important hypothesis in the study of well-being is whether people change their desires and wishes according to the circumstances in which they live in. As Inglehart (1990:212) puts it: "(...) happiness is not the result of being rich, but a temporary consequence of having recently becoming richer" . If we were able to measure the subjective well-being of individuals over time, we could control whether increasing wages cause a permanent or only temporary rise in well-being - as the aspiration hypothesis implies. Finally, scientists discuss not only which desires are included, but also how far they have to be fulfilled. Does happiness increase if one obtains simply more of a certain good, or does it increase if one obtains more of this good than others, or more of this good than one has expected? (Layard 2005).

All in all, the subjective approach can be used to give empirical answers to questions that could only be theoretically debated under the objective approach. It is this distinction that makes the subjective approach so attractive to empirical-oriented sociologists and economists. However, it must be taken into account that these analyses rest on the assumption that people's subjective evaluations of their state of life are valid and reliable measurements of well-being. A large body of research using the subjective approach is therefore preoccupied with measurement issues. ${ }^{2}$ Some of the more important findings in this realm are: Different measures of subjective well-being correlate well with one another (Fordyce 1988). Happy people are rated as happy by friends and family members (Sandvik et al. 1993; Lepper 1998; Costa und McCrae 1988). Subjective well-being is relatively stable and sensitive to changing life circumstances (Ehrhardt et al. 2000; Heady und Wearing 1991). Happy people smile more often during social interactions (Fernández-Dols und Ruiz-Belda 1990). Happy people are less likely to commit suicide (Koivumaa et al. 2001). Changes in the electrical activity of the brain and heart rate account for substantial variance in reported negative effects (Davidson et al. 2000). Taken all together "the measures of happiness seem to contain a substantial amount of valid variance" (Diener 1984: 551). ${ }^{3}$

In the context of international comparisons, an important issue is whether mere linguis-

2 A survey on various measures of subjective well-being can be found in Andrews und Robinson (1991).

3 Further evidence of this sort might be found in Andrews und Robinson (1991); Michalos (1991); Larsen und Fredrickson (1999); Schwarz und Strack (1999) and Veenhoven (1993). 
tic differences in the interpretation of the survey questions about happiness are responsible for differences in subjective well-being between countries. A closer look at Switzerland, however, reveals that country differences cannot be attributed to language per se. Regardless of the language they speak, the Swiss rank far above the Germans, Italians and French, with whom they share their languages. Similar results have been achieved for Flemish and French speaking Belgians (Inglehart und Rabier 1986:39-42). Finally, country rankings are fairly stable, regardless of the indicators used to measure subjective well-being. 


\section{Well-being in Europe}

\subsection{Country performance according to basic desires}

As stated above, nine domains are ubiquitously seen as essential for well-being: health, labour market, education, income, security, housing, family, social relationships, and environment. In this section we will illustrate research findings for each of these domains. We therefore use data from the European Quality of Life Survey (EQLS), a large scale survey project carried out on behalf of the "European Foundation for the Improvement of Living and Working Conditions". The EQLS was conducted in 2003 in 28 European Countries, including all 15 countries that were part of the EU at that time, and the ten countries that joined the EU in May 2004. In addition Turkey, Romania and Bulgaria were included in the survey project. The EQLS asked about a wide range of indicators for each of the above-mentioned domains and for some other domains as well; it is therefore an invaluable source for describing the well-being of European countries based on the objective approach. ${ }^{1}$

The values of the indicators we have selected are compiled in figure 2.1. Therefore the figure uses one graph for each domain, and the name of the respective domain is given above the graph. The value of the indicator for each country is displayed with a black marker symbol. In each graph, high values indicate "better" well-being in the respective domain. Hence, the further to the right the values of a specific country are, the higher is the quality of life in that country. The countries of the graph are presorted into three country groups. The first group are the 15 traditional EU member states; we will refer to them as the "old" EU member states (OMS). The remaining countries are separated into two further groups. The first group consists of the ten former communist or socialist countries, which are now all EU-members. We refer to these countries as transformation countries or former communist countries (FC). The remaining countries Turkey, Malta and Cyprus form a third group. These countries are neither old EU members, nor transformation countries. We will not use any specific name for them, but we will often refer to the traditional market economies to refer to the old EU members and to these three countries. For convenience we have plotted the country group's average value of each indicator as a vertical line.

When people are asked what contributes most to a good life, being in good health is top of the list (Alber und Kohler 2004). Moreover, good health and its protection is incorporated into the fundamental goals of the European Union. To show how well countries perform with regard to health, we have selected the indicator "self-rated health", which has proved to be a relatively good measure of health status (Robine et al. 2003:103).

1 The results we are presenting here can only give a very rough overview of the results ascertained by this survey in particular. Readers are therefore asked to additionally refer to the rich literature provided on the website of the European Foundation http://www. eurofound.europa.eu/. Additional information can be found in Alber et al. (2004, 2008). 

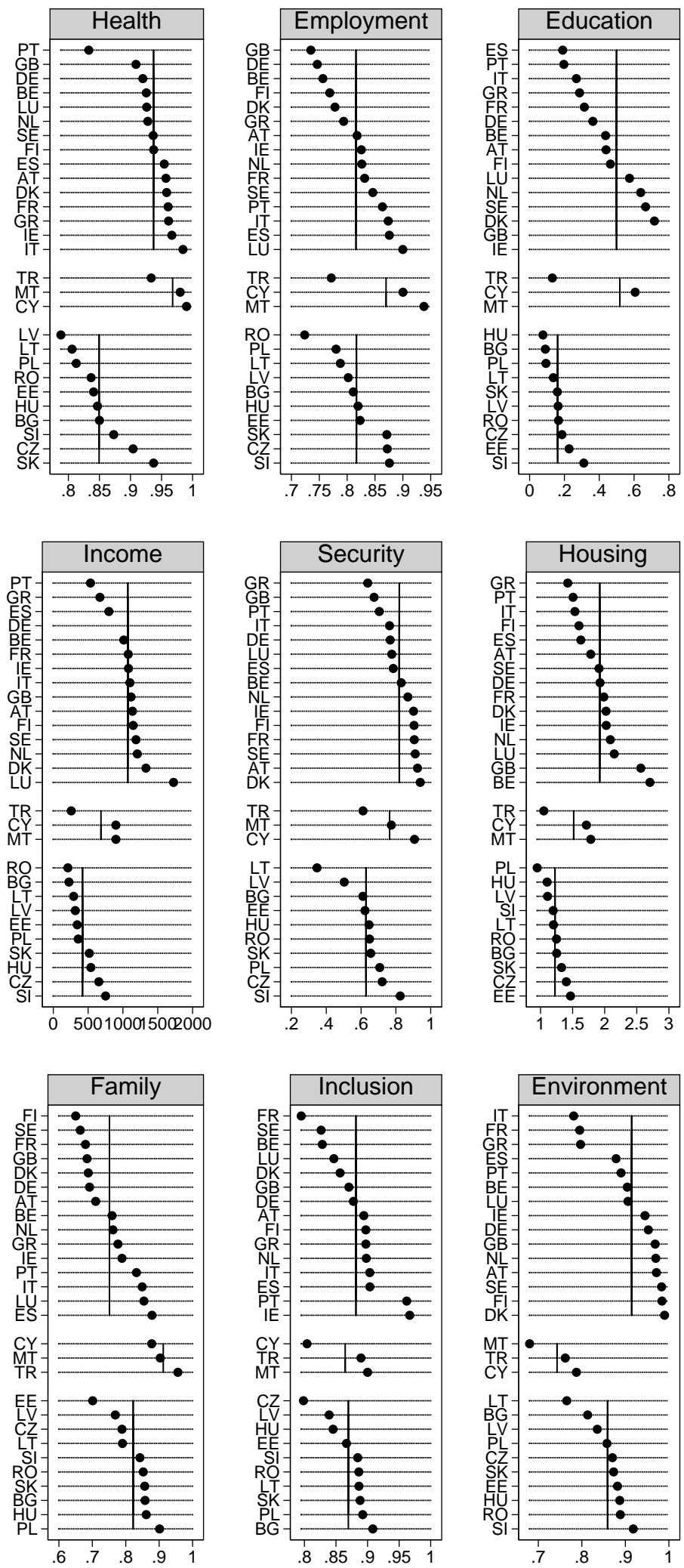

Figure 2.1: Components of well-being by country 
The EQLS asked whether the respondents regard their own health as excellent, very good, good, fair or poor. Our figure shows the proportion of people who regarded themselves at least in "fair" health. In general respondents from traditional market economies rate their health much higher than people from the transformation countries. Self rated health is especially low in Latvia, Lithuania and Poland. Out of the former group of countries, only Portugal ranks below the average of the latter group. The highest self-rating health can be found in the Mediterranean countries Malta, Cyprus, and Italy.

More and better jobs and reduced unemployment are major goals of the EU's Lisbon strategy. Employment situation is therefore a core dimension of any attempt to measure well-being across countries. In figure 2.1 we have measured integration in the labour market by the proportion of households with at least one employed member. ${ }^{2}$ The results suggest that there is no general difference in integration in the labour market between the transformation countries and the old EU- members. The major difference between countries seems to be rather within the country groups distinguished here, than between them. Integration in the labour market was especially low in the United Kingdom, in Germany and in Rumania, whereas it was high in Luxembourg, Cyprus, Malta, Slovakia, Czech Republic and Slovenia. Irrespective of the small differences in the overall labour market integration between East and West European countries, it should be noted that the working conditions tend to be worse in the former countries (Alber und Fahey 2004: 2328).

Educational skills are not only an (increasingly) important prerequisite for labour market integration, but also form the basis for social integration and participation in a modernised world. To sum up, education is an important dimension of present and expected well-being. In practice, education is often measured by the formal degree of education, and such data tend to show few differences between the transformation countries and the traditional marked economies. English language skills can be used as a more direct measure of educational attainment, particularly with a view to the needs of a modern, rapidly developing global labour market. In Figure 2 we have therefore used the proportion of EQLS respondents who state that their English reading ability is very good or quite good. The differences between the transformation countries and the traditional market economies (without United Kingdom, Ireland and Malta) are very large in this respect. Overall the proportion of people with good English reading ability is around 16 per cent in the transformation countries, but more than 40 per cent in the traditional market economies. Further analyses not presented here indicate that the ability to read English among younger people from Eastern Europe is starting to catch up with the traditional market economies (Alber und Fahey 2004:29-30).

In modern societies, money can be used to buy the goods one desires, and if people successfully match their consumer decisions to their desires they should produce what economists call utility, and others call satisfaction, happiness or well-being. Income is therefore one of the less debated dimensions of well-being. For an assessment of the overall standard of living in terms of income, figure 2.1 uses the median of the net household

2 This mirrors the incidence of jobless households used in the so called "Laeken indicators" (Atkinson et al. 2002). 
equivalence income expressed in purchasing power standards. ${ }^{3}$ By construction, this index controls for differences in the purchasing power of one Euro between countries, and for differences in household sizes. High values of this indicator can therefore be regarded as a measure of the money people have for consumption. The data in the figure clearly indicates that living standards are still much higher in the old EU member countries than in the other European countries. The poorest West European country - Portugal - is still above the average of the transformation countries, while the richest transformation country - Slovenia - is below the average of the West European countries.

The level of security was measured by a question about whether the respondents think that it is safe to walk around at night in the area in which they live. Although the majority of respondents feel rather safe or very safe in almost all countries, transformation countries seem to offer a lower level of security than the traditional market economies. This is especially true for Lithuania and Latvia, which are the only countries where the majority feels unsafe.

"The home is a place of rest and physical regeneration. ... It is the centre of family life, where children are born and raised, where socialisation takes place and family ties are nurtured." (Alber und Fahey 2004: 15) Adequate accommodation can be even a matter of survival. Hence, the importance of housing as a dimension of well-being cannot be exaggerated. For housing quality we have applied the indicator "mean number of rooms per person". Figure 2.1 suggests that housing quality is much higher in Western Europe compared to the rest of Europe. Even Greece, the country with the smallest dwellings among the old European member states, have on average larger dwellings than the Czech Republic or Estonia, where dwellings are relative large by standards of the transformation countries.

Families can be considered as the basis of the social integration of individuals in a large community, and patterns of family life therefore form an important indicator for the social cohesiveness of a country. Figure 2.1 uses the proportion of respondents not living alone as one possible indicator for the incidence of families. According to this indicator, family integration is somewhat higher in the transformation countries than in the old EU member countries. However, a closer look suggests that family integration is more connected with religious tradition than with the communist past. Among the traditional market economies, family integration is high in the catholic countries of Southern Europe (like Spain, Italy, Portugal, Cyprus, Malta), and the same is true in the transformation countries' group (Poland, Hungary, Bulgaria). Among the countries with a relatively low level of family integration are the protestant countries of Scandinavia, and the Baltic countries.

Social integration can also be provided by social relationships with persons outside the family. Figure 2.1 therefore displays the proportion of people having regular contact with friends and neighbours as another indicator for inclusion. The results show that there is little difference between the three country groups distinguished in the figure in this respect. However, there is again a high degree of inclusion among some of the catholic countries (Portugal, Ireland, Poland, Bulgaria).

3 Data for Germany are not shown because of validity problems of the income variable in the German EQLS sample. 
Finally, the local environment. The local environment is a part of living conditions that cannot be changed or influenced actively by the individual on their own. To be born into a threatening environment limits well-being, no matter how successful an individual is within this environment. The EQLS asks about complaints of the local environment in four respects: noise, air pollution, lack of access to green areas, and water quality. We present the proportion of respondents that have only a few or even no reasons to complain. The data in figure 2.1 once again suggest a division between the former communist countries and the old EU-members. However, this time the East-West division belt is accompanied by sharp North-South differentiation. The lowest degree of criticism can be found in the three Scandinavian countries, while criticism with regard to the environment is widespread in Italy, Greece, Malta, Turkey, and Cyprus.

The discussion, so far, might be rich in detail but an overall picture cannot be easily drawn from it. This is a general problem of the objective approach. Applications of the objective approach often result in the wish to produce a summary index from all the dimensions used; the United Nations "Human development index" is one of the most successful examples of such attempts. However, the value of such summary measures has been hotly debated, and it seems that this debate really cannot come to an end. In our view, the reason for the fruitlessness of these debates is built into the objective approach. Because it is an operational definition (section 1.2), it lacks an external criteria for the selection (and weighting) of the different domains. Fahey et al. (2003:59) therefore conclude that attempts to construct a summary index should be avoided.

In what follows we try to go for an intermediate solution, something in-between an arbitrary construction of a summary index and the complete avoidance of providing an overall picture. We try to draw an overall picture of well-being in Europe by using a biplot as device. Although the statistical foundations of biplots are fairly complicated ${ }^{4}$, they are easy to interpret; figure 2.2 is the biplot of the data shown in figure 2.1.

Basically, biplots show as much information as possible of a multivariate description in a two-dimensional space. They therefore use arrows for showing information about the variables (the dimensions of well-being) and marker-symbols for displaying information about the observations (countries). If the angle between the arrows is close to zero or 180, the correlation between the respective dimension of well-being will be high; the correlation will be low if the angle between the arrows approach 90 or 270 degrees. Hence, income, security, housing and education are closely related, forming a well-being dimension that might be termed as "modernisation". Family and environment are fairly uncorrelated to this modernisation dimension; incidentally, where family integration is high, quality of the environment tends to be low, and vice versa.

The positions of the countries along the variable arrows approximate the values of the country on the respective dimension of well-being. Cyprus, for example, appears far out on the arrow for health, meaning that self-rated health is high for Cyprus. As a conse-

4 A biplot can be seen as a graphical device of a principal components analysis (PCA). It shows observations (countries) and variables (dimensions of well-being) in the space of the first two principal components. Biplots allow us to depict variable values, correlations between variables, and Euclidean distances of a multidimensional space at one time. They were originally invented by Gabriel (1971). An easy-to-read introduction with many interpretation examples is given by Kohler und Luniak (2005). 


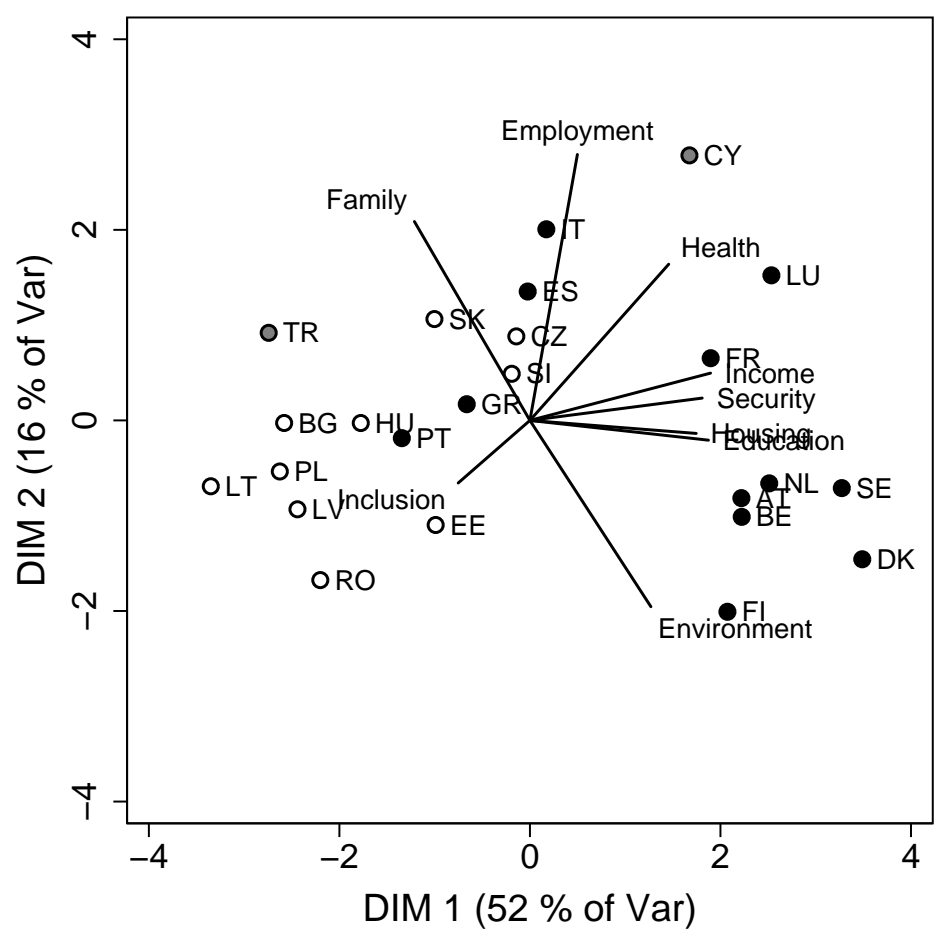

Figure 2.2: Biplot of the components of well-being

quence, countries that appear close together in the figure can be said to have a similar "well-being". 5 A group of 5 countries form such a cluster: Austria, Netherlands, Sweden, Denmark, and Belgium. These countries can be characterised as countries with high values on the modernisation dimensions (income, security, housing, and education), intermediate values on health and employment and fairly low values of family integration. No other countries form an obvious cluster. Obviously, the transformation countries tend to have lower values on the modernisation dimension than the old EU members. However, Portugal, Greece, the Czech Republic and Slovenia cross-cut the division between old and new member states on this dimension. The countries differ in a less systematic way according to the other dimensions of well-being; at least a slight differentiation between a family-oriented south and a less family-oriented north is visible.

\subsection{Country performance according to subjective well-being}

We will now describe the well-being in European countries by using an indicator for subjective well-being. As explained in chapter 1, subjective well-being is sometimes seen as yet another dimension of well-being in the objective approach. Further, it is seen as the main indicator for well-being in the subjective approach. In this sense, this section can be

5 Countries that do not have a value on one of the indicators shown in figure 2.1 cannot be used in the biplot. 


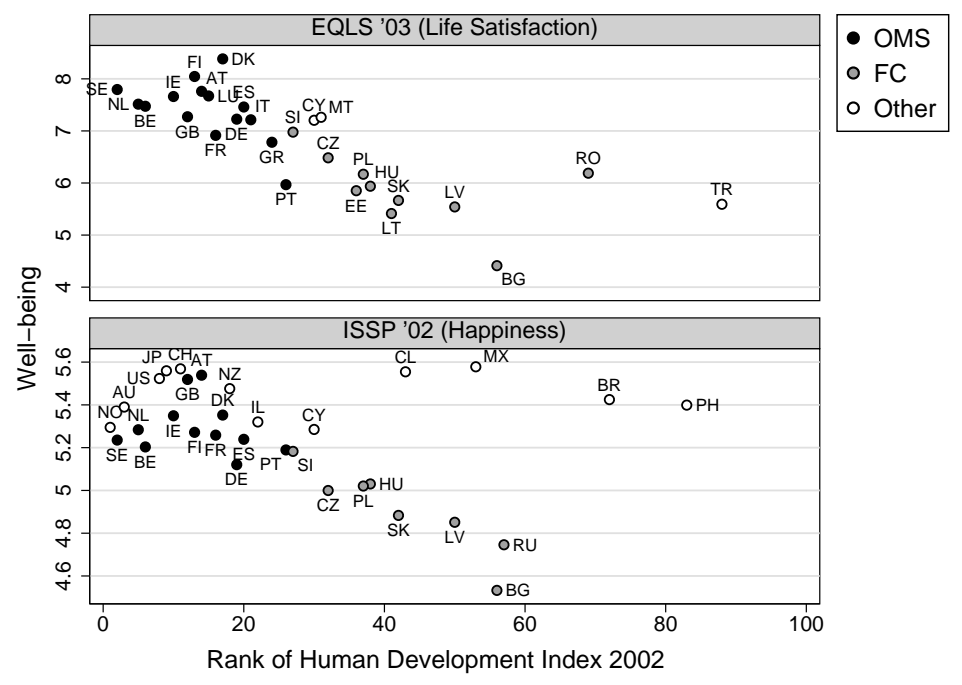

Figure 2.3: Subjective well-being by ranked order of the Human Development Index for EQLS and ISSP

seen as an application of either the objective approach or the subjective approach.

In figure 2.3 we have plotted two different indicators of subjective well-being by a manifestation of objective well-being. The two measures of subjective well-being go back to the question about life satisfaction from the EQLS $2003^{6}$ and a question on happiness taken from the 2002 International Social Survey Programme (ISSP) ${ }^{7} .{ }^{8}$ Countries are ranked according to the Human Development Index, a summary index of GDP per capita, life expectancy and educational attainment used by the United Nations human development reports.

The first insight of figure 2.3 is the strong correlation between information about a country's well-being derived from summary statistics (objective approach) and the two measures for subjective well-being. Consequently, the core results of the previous section are also visible when we use indicators of subjective well-being: there is a high betweencountry variance in well-being and a sharp distinction of well-being between the old European member states (OMS) and the former communist countries (FC). Life satisfaction is highest in the Scandinavian and Continental European Countries and lowest in the Baltic

6 The question was: "All things considered, how satisfied would you say you are with your life these days? Please tell me on a scale of one to ten, where one means very dissatisfied and ten means very satisfied."

7 The question was: "If you were to consider your life in general, how happy or unhappy would you say you are, on the whole". Respondents could answer on a scale from 1 to 7 with 1 being completely happy and 7 completely unhappy. The scale was reversed for subsequent analysis.

8 The EQLS has been described in some detail in the previous section. The ISSP 2002 is round 15 of a continuing program of cross-national surveys. Between the end of 2001 and February 2004, surveys were carried out in 33 countries, 20 of them being EU members or EU candidates. The target population of the samples are residents of age 18 and older. Sample sizes vary between 1,000 in Latvia and 2,947 in United Kingdom. The ISSP has been made available by the Central Archive for Empirical Social Research at the University of Cologne. The study number (ZA-Nr.) is s3880. 


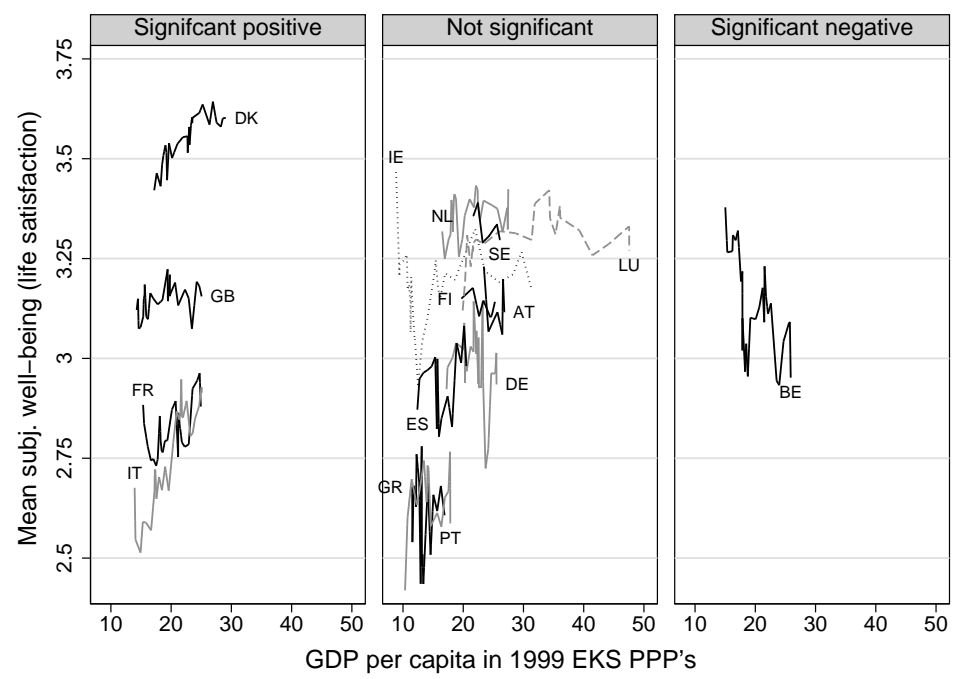

Figure 2.4: Subjective well-being by GDP based on Eurobarometer data from 1970 to 2002

States and in Bulgaria. Portugal is the only old member state with a level of life satisfaction comparable to the former communist countries. Additionally, the lower panel of the figure reveals that the mean happiness scores of the old European member states are similar to those countries which share their high objective quality of life (i.e. USA, Japan, Switzerland and Norway).

The figure suggests that well-being is causally related to economic success. In fact, if we compare different satisfaction levels between countries, the most obvious explanation is that well-being is related to indicators of a nation's prosperity. The lower the GDP per capita in a country, the lower are satisfaction levels throughout the population (Inglehart und Klingemann 2000; Di Tella et al. 2001; Fahey und Smyth 2004). However, there is another way of looking at the 'economic- success- hypothesis': If the hypothesis is true, this should imply that rising GDP in a specific country should also raise the average well-being in this country. To analyse this implication, we have plotted in figure 2.4 the means of general life-satisfaction measured at several points in time between 1970 and 2002 against the Gross Domestic Product (GDP) of the respective years. ${ }^{9}$ If the guiding hypothesis were true, all the lines in the figure should increase, which is obviously not the case: The wealth of a nation correlates significantly with life satisfaction in only four of the 15 EU old member states (Denmark, United Kingdom, France and Italy). In most countries life-satisfaction and GDP do vary independently from another, and in Belgium there is even a significant negative relationship.

These results mirror a well established finding that rising prosperity in the long run does not go along with increasing satisfaction levels (Easterlin 1974; Inglehart und Rabier

9 The data used for this plot is the Mannheim Eurobarometer Trend File. The data set has been made available by the Central Archive for Empirical Social Research at the University of Cologne. The study number (ZA-Nr.) is s3521. For figure 2.4 the dataset has been enriched by some additional years by the WZB. 
1986; Easterlin 1995; Lane 1998; Graham und Pettinato 2001; Hagerty und Veenhoven 2003; Blanchflower und Oswald 2004; Easterlin 2005). Given the high correlation between subjective well-being and GDP across countries, this finding is a paradoxical result. It has vitalised the controversy about the origin of subjective well-being for decades. All in all, three explanations for it can be found in the literature:

- Other important aspects remain hidden behind economic affluence. Richer countries tend to have more stable democracies, less corruption, better average health care supply, and basic human and social rights are secured more effectively. These factors are more relevant than economic success in promoting overall well-being. Therefore, Inglehart (1990) argues for a cultural explanation for country differences. Such cultural factors might also explain the outstanding position of Chile, Mexico, Brazil and the Philippines in figure 2.3, which reveal high levels of subjective wellbeing despite relatively less advanced economies and lower levels of modernisation. However, referring to cultural features remains a bit vague.

- It is assumed that it is not the absolute level of income that matters most, but rather one's position relative to other individuals (Irwin 1944; Duesenberry 1949; Becker 1974; Easterlin 1974, 2001; Clark und Oswald 1996; Neumark und Postlewaite 1998; Firebaugh und Tach 2005; Layard 2005). Consequently, a rise in average income fails to raise the happiness of all.

- The utility of additional material goods is only transitory. Individuals compare their possessions with those of their own past and are commonly satisfied when they notice progress towards more goods or a better quality. They then quickly fall back to the initial level of satisfaction (Helson 1964; Brickman und Campbell 1971; Campbell et al. 1976; Parducci 1995; Frederick und Loewenstein 1999).

Hence, this first empirical impression of how subjective well-being is distributed across Europe suggests how challenging the attempt is to understand its determinants comprehensively. Income, our starting point, is undoubtedly important, but not completely sufficient. In the following section we will shed further light on factors which explain subjective well-being within and across countries. 


\section{Well-being and dimensions of social inequality}

In this section we will use the subjective approach of figure 1.1 in order to link the study of well-being with studies of social inequality. As already mentioned, many of the dimensions that constitute well-being are dimensions of social inequality. One of the core topics of sociological research on social inequality is the question of which core dimensions of social inequality structure people's life chances and behaviour. As it stands this question is strongly linked to the question about the core dimensions of well-being in the objective approach. Using subjective well-being as an indicator for the overall quality of life allows the analysis of the correlations between subjective well-being and dimensions of social inequality in order to give answers to these questions.

The aim of this section is twofold. On the one hand, we would like to assemble known empirical results concerning the connection between dimensions of social inequality and subjective well-being; on the other hand we would like to illustrate the effects of each inequality dimension for Europe as a whole. We hope to show how relevant the dimensions of social inequality are for the Europeans as one single group. For this purpose, we have used a series of regression models relying on data from the EQLS (see section 2.1). The results of the various regression models are compiled together in table 3.1 on page 24 . Some particularities of those regression models are worth noting before dealing with the effects of each inequality dimensions.

\subsection{A primer on the regression models}

We apply linear regression models to describe the influence of individually experienced inequality on subjective well-being. The dependent variable of all regression models is life satisfaction, measured on a 10- point scale from 1 (unsatisfied) to 10 (satisfied); thus high values represent high levels of life satisfaction. The influence of each inequality dimension is given by its unstandardised regression coefficient. A regression-coefficient of 1.5 means that a one-unit increase of an independent variable increases the average life satisfaction by 1.5 points. Most independent variables of the regression models are dichotomies, so that this interpretation can be further simplified. A dichotomous variable can increase by one unit only once. Therefore the regression-coefficient of 1.5 would mean that the average life satisfaction of one group is 1.5 points higher than those of the other.

In the first column of table 3.1 we show the gross impact of each inequality dimension. By this we mean the effect of the respective inequality dimension without controlling for any of the variables. In the subsequent columns we add other inequality dimensions step by step. The order of the inclusion is guided by a rough idea of a causal order amongst the inequality dimensions. We have assumed that age and gender are exogenous to all the other inequality dimensions, and that education, employment status, social class, and income are exogenous to housing quality, sociability or life style. 
The regression models are based on data from 28 countries. These countries are heterogeneous in many respects. They have different compositions of socio-demographic attributes, and there might be cultural influences on how to react on survey questions, to name just a few aspects countries can differ in. In order to carry out a statistical analysis of the impact of inequality on well-being, the heterogeneity has to be controlled, so that the impact of an inequality dimension cannot be a simple consequence of specific country characteristics. We have controlled the heterogeneity of countries by controlling for country dummies in all models, including those for calculating the gross effects. Hence, all coefficients in the table cannot be biased due to any general country-characteristic.

At the bottom of table 3.1 we print out the variance explained by countries. These numbers can be regarded as a measure of how all country-specific characteristics taken together impact on life satisfaction. Without any further individual variables, around 20 percent of the variance of life satisfaction is explained by the country as such, and even after controlling for all inequality dimensions, this number stays at around 14 percent. This means that only a small part of the country differences in subjective well-being can be explained by individual composition effects. In other words, countries do not differ so much in well-being because some countries have a higher fraction of rich, healthy or sociable persons than others. There must be other characteristics of countries that are responsible for the country differences: Culture, habits, traditions of norms and values and welfare policy characteristics are promising candidates in this respect.

Finally, the second last row of table 3.1 shows how much of the variance of satisfaction can be explained by the inequality dimensions used in each model. Note that all inequality factors together explain about 22 percent of the variance of life satisfaction. Adding both variance components together leads to an overall explained variance explained of 36 percent. Hence, important reasons for life satisfaction variation exist that are neither a country-characteristic, nor a dimension of social inequality. These factors include genetics, personality, and measurement errors (Hamer 1996; Lykken und Tellegen 1996; Arvey et al. 1989; Inglehart und Klingemann 2000).

\subsection{Effects of social inequality on subjective well-being}

\section{Gender}

Are there differences in subjective well-being between men and women? In a study of 16 nations, Inglehart (1990:222) found that life satisfaction is marginally higher among women than among men, with Russia being the exceptional case, where it is the other way around. At the same time, women do, however, also report higher levels of depression than men (Donovan und Halpern 2002). A recent book by Halpern (2005) explains these seemingly contradictory findings with the hypothesis that women are more socially connected and therefore more exposed to the satisfactions and disappointments of their environment. We cannot confirm this hypothesis with our results for 28 European countries: Overall, men are more satisfied than women, although only very slightly. A gender difference only becomes visible if one also controls for measures of sociability, like marital status, working for voluntary organisations and contacts with neighbours, and friends. These findings 


\begin{tabular}{|c|c|c|c|c|c|c|c|}
\hline & Gross & (1) & (2) & (3) & (4) & (5) & (6) \\
\hline \multicolumn{8}{|c|}{ Gender (reference: women) } \\
\hline Men & -0.00 & -0.00 & -0.04 & -0.04 & $-0.11 *$ & $-0.09 *$ & $-0.14 *$ \\
\hline \multicolumn{8}{|l|}{ Age (metric, in years) } \\
\hline Age & $-0.01 *$ & $-0.01 *$ & $-0.00 *$ & $-0.00 *$ & $-0.00 *$ & $-0.00 *$ & $0.01 *$ \\
\hline Age (squared) & $0.00 *$ & $0.00 *$ & $0.00 *$ & $0.00 *$ & $0.00 *$ & $0.00 *$ & $0.00 *$ \\
\hline \multicolumn{8}{|c|}{ Type of community (reference: rural) } \\
\hline Urban & -0.01 & 0.01 & $0.16 *$ & $0.21 *$ & $0.13 *$ & $0.13 *$ & $0.11 *$ \\
\hline \multicolumn{8}{|c|}{ Income (reference: 1st within country quartile) } \\
\hline 2nd quartile & $0.42 *$ & & $0.36 *$ & $0.31 *$ & $0.28 *$ & $0.28 *$ & $0.23 *$ \\
\hline 3rd quartile & $0.82 *$ & & $0.69 *$ & $0.60 *$ & $0.52 *$ & $0.52 *$ & $0.45 *$ \\
\hline 4th quartile & $1.17 *$ & & $0.97 *$ & $0.87 *$ & $0.77 *$ & $0.76 *$ & $0.65 *$ \\
\hline \multicolumn{8}{|c|}{ Employment status (reference: employed) } \\
\hline Homemaker & $-0.19 *$ & & 0.11 & 0.10 & -0.05 & -0.02 & 0.05 \\
\hline Unemployed & $-1.19 *$ & & $-0.80 *$ & $-0.75 *$ & $-0.72 *$ & $-0.69 *$ & $-0.64 *$ \\
\hline Retired & $-0.35 *$ & & $-0.13 *$ & $-0.12 *$ & $-0.13 *$ & -0.10 & $0.17 *$ \\
\hline Still in education/other & $0.13 *$ & & $0.19 *$ & $0.18 *$ & $0.20 *$ & $0.17 *$ & 0.12 \\
\hline \multicolumn{8}{|c|}{ Class (reference: upper white collar) } \\
\hline Lower white collar & $-0.29 *$ & & $-0.13 *$ & $-0.12 *$ & $-0.09 *$ & -0.07 & -0.05 \\
\hline Self employed & $-0.22 *$ & & -0.10 & -0.11 & -0.10 & -0.08 & -0.06 \\
\hline Skilled Worker & $-0.72 *$ & & $-0.36 *$ & $-0.32 *$ & $-0.28 *$ & $-0.24 *$ & $-0.17 *$ \\
\hline Non skilled worker & $-0.94 *$ & & $-0.49 *$ & $-0.43 *$ & $-0.37 *$ & $-0.32 *$ & $-0.20 *$ \\
\hline Farmer & $-0.61 *$ & & $-0.23 *$ & -0.18 & -0.18 & -0.19 & -0.05 \\
\hline Other & $-0.33 *$ & & -0.13 & -0.10 & -0.04 & -0.02 & 0.05 \\
\hline \multicolumn{8}{|l|}{ Education (reference: low) } \\
\hline Intermediate & $0.33 *$ & & $0.14 *$ & $0.10 *$ & $0.09 *$ & $0.09 *$ & 0.02 \\
\hline High & $0.65 *$ & & $0.20 *$ & $0.16 *$ & $0.15 *$ & $0.12 *$ & 0.03 \\
\hline Other & $0.49 *$ & & -0.02 & -0.06 & -0.03 & -0.05 & -0.06 \\
\hline \multicolumn{8}{|l|}{ Housing } \\
\hline per person & 0.02 & & & $-0 .($ & $0.06 *$ & $0.06 *$ & $0.04 *$ \\
\hline Accomodation problems & $-0.55 *$ & & & -0 & $-0.41 *$ & $-0.40 *$ & $-0.31 *$ \\
\hline \multicolumn{8}{|c|}{ Marital status (reference: married, living with partner) } \\
\hline Separated/divorced & $-0.81 *$ & & & & $-0.68 *$ & $-0.65 *$ & $-0.51 *$ \\
\hline Widowed & $-0.54 *$ & & & & $-0.57 *$ & $-0.58 *$ & $-0.43 *$ \\
\hline Single, never married & $-0.19 *$ & & & & $-0.46 *$ & $-0.45 *$ & $-0.34 *$ \\
\hline \multicolumn{8}{|c|}{ Contacts with friends/neighbours (reference: no) } \\
\hline Yes & $0.33 *$ & & & & $0.34 *$ & $0.32 *$ & $0.26 *$ \\
\hline \multicolumn{8}{|c|}{ Voluntary work (refence: no) } \\
\hline Yes & $0.46 *$ & & & & $0.30 *$ & $0.24 *$ & $0.18 *$ \\
\hline \multicolumn{8}{|c|}{ Church attendanence (metric, 7 point scale) } \\
\hline Church attendance & $0.07 *$ & & & & & $0.07 *$ & $0.06 *$ \\
\hline \multicolumn{8}{|c|}{ Internet user (reference: no) } \\
\hline Yes & $0.58 *$ & & & & & $0.18 *$ & $0.19 *$ \\
\hline \multicolumn{8}{|c|}{ Long term illness (reference: no) } \\
\hline Long term illness & $-0.78 *$ & & & & & & $0.10 *$ \\
\hline \multicolumn{8}{|c|}{ Health satisfaction (metric, 11 point scale) } \\
\hline Health satisfaction & $0.31 *$ & & & & & & $0.30 *$ \\
\hline Constant & n.a. & $6.64 *$ & $6.11 *$ & $6.40 *$ & $6.18 *$ & $5.88 *$ & $3.77 *$ \\
\hline$\rho$ (Var. exp. by country) & 0.20 & 0.19 & 0.20 & 0.18 & 0.17 & 0.17 & 0.14 \\
\hline$r^{2}$ (within) & n.a. & 0.01 & 0.08 & 0.10 & 0.12 & 0.12 & 0.22 \\
\hline$n$ & 18600 & 18600 & 18600 & 18600 & 18600 & 18600 & 18600 \\
\hline
\end{tabular}

Table 3.1: Multiple linear Regression models of well-being on dimensions of inequality 
suggest just the opposite explanation compared to the patterns found by Halpern.

Age

Most studies report lower levels of satisfaction with one's life in general for middle-aged people, and higher levels for the oldest and youngest age groups (Campbell et al. 1976; Herzog et al. 1982; Campbell 1981; Inglehart 1990; Helliwell 2003; Blanchflower und Oswald 2004). In table 3.1 the curvilinear relationship between age and life satisfaction is modelled by a quadratic age-term, and it turns out that life satisfaction in fact first diminishes with age, but then goes up again. However it must also be noted that the curvilinearity disappears after controlling for health. This indicates that the lower life satisfaction of middle-aged people is mediated by their lower health satisfaction.

\section{Location}

A further possible cause of well-being is the dichotomy between urban and rural areas, or, between what has been called the "metropolitan corridors" and beyond. It is argued that the speed of economic and social development in Europe has been increased in the highly urbanised belt running from London to northern Italy, leaving the rural areas offside as slow developing and deprived regions. Some time ago, Mooser (1983) showed that living in rural areas creates a living situation that is different from that in cities in many respects. Living in the countryside is typically connected with better quality of the environment, but also with difficulties, and hence high costs, in reaching the workplace, shopping and cultural facilities, medical assistance etc. On the other hand accommodation costs tend to be lower in the countryside, and it is possible to cut the cost of living by farming on a sideline basis. People living in the countryside more often own inherited brown-fields than people living in cities. In the countryside, friends are more often recruited from the close neighbourhood, etc. Hence, there are many reasons to believe that well-being is different between the urban and rural population, although it is not quite clear what direction the difference might show.

The EQLS offers only a crude measure of the urban/rural dichotomy, based on the ratings of the respondent. As shown in table 3.1, the European urban and rural population does not differ in their subjective well-being overall. However, the results also reveal that the association is covered by the fact that people in the countryside typically have somewhat higher incomes than those living in cities. If one compares urban and rural population holding income on a constant level, the urban population turns out to be more satisfied with their lives. Hence, the advantages of living in a city seem to count more than the disadvantages, and many people living in the countryside probably just don't move into the cities because they want to save money. However, one should probably not overinterpret these findings. People living in a rural area quite often have chosen to live there, which means that they have a preference to do so. Hence, if they had lived in a city, they would have been even less satisfied. 
Income

Income is clearly one of the most frequently studied causes of subjective well-being under the subjective approach. It is a robust and general result of these studies that richer people, on average, report higher subjective well-being (Frey und Stutzer 2002:409). The effect of income has been demonstrated in regions as different as the USA (Blanchflower und Oswald 2004), the EU member states (Böhnke 2005; Delhey 2004; Di Tella et al. 2001), Switzerland (Frey und Stutzer 2000) and Latin America (Graham und Pettinato 2001). It is also a common finding that the relationship between income and well-being is nonlinear, i.e. the income effect is stronger with low incomes and extenuates weaker with higher ones (Argyle 1999; Frey und Stutzer 2002). However, although there is not much doubt that income has a positive effect on well-being, the size of the income-effect is usually considered as small compared to other factors such as unemployment and divorce (Diener et al. 1999; Gardner und Oswald 2001; Helliwell 2003). ${ }^{1}$.

Looking at the effect of income on the population of the 28 countries covered by the EQLS, we can replicate most, if not all, of the above mentioned findings. Life satisfaction increases steadily from the lower to the higher income quartiles, although the gain in life satisfaction diminishes as one steps along the income range. Without controlling any further variables, people in the highest income quartile have on average a 1.17 point higher life satisfaction than people in the lowest one. The general appearance of the income effect stays the same even after controlling for other variables, but it diminishes slightly when controlling for other dimensions of socio-economic status, for housing- quality, marital status and health- status. Hence, the gross effect of income is partly caused by the nonmonetary effects of unemployment and typical characteristics of the occupations of those with high income, and it is partly mediated through its effect on housing quality, on family situation and on health conditions.

\section{Employment, occupation and social class}

Integration in the labour market and the quality of the employment position is another important aspect of the objective approach when studying well-being. Among scholars of the subjective approach there is also little doubt that unemployment is linked to wellbeing because of its connection to income loss. However, the major question is whether unemployment is also effective in non-pecuniary ways (Feather 1990). The answer to this question is of crucial importance when considering assertions that the social benefit system is exploited by free riders, who choose leisure time instead of regular work. Such assertions imply that, after controlling for income, the subjective well-being of unemployed persons should be higher than that of economically active persons. Available research, however, clearly indicates that this is not the case. Subjective well being is lower

1 Another important line of research is on the direction of causality. It could either be that rich people are more satisfied with their lives, or that happy people are economically more successful. The study of the causal direction requires, at least, longitudinal data, which is not available for Europe as a whole. Studies of well-being before and after sudden and unexpected gains of income suggest that income in fact causes gains in happiness (Smith 1995; Brickman et al. 1978; Gardner und Oswald 2001) 
for unemployed persons, even after controlling for personal income and various other factors (Clark und Oswald 1994; Di Tella et al. 2001; Delhey 2004; Böhnke 2006). Hence, unemployed persons are on average less happy than the economically active, even if they have the same income. This means that the unemployed do not enjoy their leisure time, as is often supposed. On the contrary, unemployment seems to produce depression and anxiety, and results in a loss of self-esteem and personal control (Goldsmith et al. 1996). Böhnke (2005) found that unemployment also leads to strains in personal relationships. In the long run the psychological cost of unemployment seem to diminish a little, however (Clark et al. 2001). ${ }^{2}$.

Most empirical analyses differentiate only between unemployed or economically inactive persons on the one hand, and the economically active on the other. Therefore, far less is known about the consequences of the different types of economic inactivity for well-being. This is a bit surprising, because retirement and homemaking provide interesting control cases for some of the theoretical reasoning made in the context of the consequences of unemployment. Retirement, for example, leads to a similar life situation to unemployment in respect of leisure time and income loss, but it is very dissimilar from unemployment with respect to the stigmatisation attached to it. If it were the stigmatisation of unemployment that causes the lower life satisfaction of the unemployed, the life satisfaction of retired people should be higher than those of unemployed. Probably the life satisfaction of the retired is even higher than that of the economically active, because of the leisure time they have on their disposal, which might be, however, visible only after controlling for their physical ability to actually take advantage of their leisure time. Yet another case is homemaking. Homemaking is not stigmatised, and it is questionable whether homemakers have more leisure time than the economically active. Comparing the well-being of homemakers and the economically active might therefore bring up a sort of psychological utility of employment. Such psychological utilities of employment would not just be the other side of the coin of the psychological costs of unemployment. While the latter operates through stigmatisation, the former stems from the explicit acceptance or "social approval" (Wippler 1990: 189) by colleagues and business partners, as well as from prestige and the self-realization at work. Unlike many paid jobs, homemaking does not produce a finished piece of work and is more likely to resemble the Sisyphean challenge. Moreover, lack of social approval by other family members is a frequent source of dissatisfaction for homemakers. In our empirical illustration of the effect of labour market attachment on life satisfaction for Europe, we have therefore not only differentiated between economically active and inactive respondents, but also between the three mentioned types of the economically inactive.

Looking at the results in table 3.1, the finding that the unemployed are less satisfied with their lives can be replicated for the entire European society. Overall, the unemployed are about 1.19 points less satisfied than the economically active. The difference diminishes considerably when controlling for income, which is an indicator of the monetary effects

2 There is also a debate about the causal relationship between unemployment and well-being, i.e. do unhappy people become unemployed? Available research suggests that the main causality runs from unemployment to unhappiness, and not vice versa (Dew et al. 1992; Graetz 1993; Winkelmann und Winkelmann 1998; Marks 1999) 
of unemployment. The remaining effect of 0.80 , on the other hand, represents the nonmonetary effect of being unemployed. Since the effect does not diminish much further when controlling for further control variables, it seems that this non-monetary part operates fairly directly as psychological costs. However, this non-monetary unemployment effect also operates through sociability to a slight extent, and can also be explained with reference to health problems.

The gross effect of retirement shows that retired people are less satisfied with their lives than the economically active, but more satisfied than the unemployed. Although reduced in size, this general pattern remains fairly stable when controlling for income, and most other dimensions of social inequality. However, after controlling for health, retirement turns out to have a positive effect on life satisfaction, which fits well to the theoretical considerations made above. In short, retired people are less satisfied than the economically active because they have a lower income and more often suffer from health problems, but if they do not, they will be even more satisfied than the economically active.

The effect of homemaking changes considerably depending on which factors are additionally controlled. Overall, homemakers are less satisfied than economically active, but more satisfied than unemployed or retired persons. If one only compares homemakers and the economically active at the same income-level, it turns out that homemakers are in fact slightly more satisfied with their lives than employees. Hence, the negative effect of homemaking stems from income-losses, which are typical for male breadwinner households in comparison to dual earner households. But why are the homemakers more satisfied with their lives than the economically active? A look at model 4 in table offers an explanation 3.1. In this model, several indicators for sociability, including marital status, are added, leading again to a change in the sign of the homemaker effect. The employment status of homemaking is typically connected with being part of a married couple, and married couples are typically happier than anybody else. Hence, the slightly higher life satisfaction of homemakers has its roots in a satisfying family life. Finally, after including indicators for the physical health, home-makers yet again have a slightly higher life satisfaction, although they do not significantly differ from the economically active.

One more result from the comparison of home-makers and the economically active is important: we can only find, at best, a mild sign of a psychological utility of being economical active. Several explanations for that come to our minds. It could be that the social prestige of homemakers is that of the occupied person in the household, and homemakers therefore also share a part of the "psychological utility" of the occupied person. Another explanation could be that it is not true that any kind of occupation produces a psychological utility. Only occupations with working conditions that support interactions with colleagues and self-realization can offer a psychological utility of paid work. This brings us to the inequality dimension of social class.

It has been shown that many of the typical features of work in a labour-divided environment reduce job satisfaction, which in turn strongly effects overall subjective well-being. Besides good pay and job security, such features are opportunities for personal control, for skill use, and for interpersonal contacts, as well as supportive supervision, future expectations, and variety (Warr 1999; Clark 1998; Clark et al. 2001). Social class provides an indicator for several of these features of the work environment. Class positions with 
a working contract are, for example, highly divided, offer little opportunity for skill use and personal control, and career prospects are relatively limited. Higher service class positions, on the other hand, are seen as favourable in many of those aspects (Goldthorpe 1982; Erikson und Goldthorpe 1992). Looking at the impact of social class on general life satisfaction given in table 3.1, we can see that upper white collar classes are more satisfied with their lives than any other class. A major amount of the difference between the classes is however mediated by the monetary effects of the occupations. After controlling for income, the self-employed do not differ significantly from upper white collar anymore. ${ }^{3}$ Hence, the non-monetary aspects of higher white collar classes and self employment is relatively similar. The main difference is between higher white collar positions on the one hand, and working class positions on the other.

\section{Education}

Although education is a an undisputed component of well-being in the objective approach, applications of the subjective approach show that education generally has only small effects on life satisfaction, and that these effects seem to be mediated by income, health and social capital (Diener et al. 1999; Helliwell 2003). However, these results do not turn out in our European dataset. Although much of the gross education ${ }^{4}$ effect is mediated by its effect on income, the higher educated are more satisfied with their lives even after controlling for the various other aspects of the socio-economic status and for measures of sociability. It is only when controlling for health satisfaction and long-term illness that the education effect becomes insignificant. One might conclude then that the higher educated might be more satisfied because they live in healthier conditions. However, it must be remembered that subjective health evaluations of the sort used in the models are chronically error prone, and often contain more valid information about personality than about objective health status (Okun und George 1984). One could also explain the education effect by personality differences between the different educational groups.

\section{Housing}

Despite its utmost importance as a component of well-being in the objective approach, there has been only sparse analysis that looks at the effects of housing quality on life satisfaction so far. We know from several studies that having a nice home is mentioned among the most important factors contributing to quality of life (Burns und Grebler 1986; Kiel und Mieszkowski 1990; Delhey 2004). Using data from the EQLS, Domanski und Alber (2006: 102-104) show that housing deficits like rotten windows or lack of flushing toilets strongly influence the general life satisfaction of Europeans. Other factors, like the quality of the housing environment, or the number of rooms seem to be less important. Ownership itself does produce higher life satisfaction in Western Europe, but not in the former communist countries. This pattern has been called the "housing paradox" in Eastern Europe, and can be explained by the rapid privatisation policies carried out during the

3 Self-employed income is typically relatively low in Eastern Europe, unlike in Western Europe.

4 Education was measured as terminal education age in the EQLS. 
transformation.

In table 3.1 we replicate an analysis made by Domanski und Alber (2006) with a slight variation. Accommodation problems are measured by counting how many deficits people perceive (rotten windows, no flushing toilet, damp leaks) with regard to their home. We also include information about shortage of space, which is measured in objective terms by the number of rooms per person: Accommodation problems lower subjective well-being considerably, although partly so because they are indicative of low income. The effect of accommodation problems diminishes further when controlling for health, which might be taken as a sign that serious deficits of housing cause health problems. In addition, the table illustrates the relative small effect of the dwelling-size for satisfaction with life in general.

\section{Family and inclusion}

Many studies have dealt with the impact of social relationships on subjective well-being and showed, for example, the positive influence of marriage on life satisfaction. Divorce, separation or widowhood reduce subjective well-being to a remarkable extent, even when income is taken into account (Diener et al. 1999; Böhnke 2005). Other findings underline the importance of social relations outside the family, and it has also been shown that social engagement, sports activities, and participation interact with positive well-being (Helliwell 2001). Even the negative effects of unemployment on subjective well-being can be buffered by strong supporting networks (Böhnke 2004).

In order to estimate the effects of sociability on well-being for Europe, we applied three different indicators, namely marital status, having regular contacts with friends or neighbours, and doing voluntary work. The results indicate that married persons are generally more satisfied with their lives than others. The difference is particularly strong between married and divorced persons comparable to the difference of being in the 3rd income quartile instead of the lowest. The gross effect of being single in comparison to being married is relatively small, but rises considerably after controlling for age. Hence, if one compares singles with married persons of the same age, the positive effect of marriage stands out more clearly. People who have regular contacts with friends and neighbours, or who meet others because they actively participate in voluntary organisations, also have higher subjective well-being rates. The effect of working for voluntary organisations can thereby be partly traced back to rich, employed, higher educated persons with upper white collar occupations, which supports the idea that being integrated in favourable working relationships also favours social relations outside the immediate working environment.

\section{Life style}

Life style is one of the most recently detected dimensions of social inequality. Based on concepts found in the work of Max Weber or Georg Simmel, sociologists conceptualise life styles as a multidimensional concept formed by activities and expressive preferences. They empirically measure life styles as combined indices from a huge number of leisure time activities and attitudes (Spellerberg 1995; Otte 2004). In a 1976 survey, respondents were asked whether they consider leisure or work as more important for their subjective 
well-being. More than 40 percent of employed people stated that work is more important to them; even 34 percent of housewives were of this opinion (Veroff et al. 1981: 261-262). However as Lane (2000: 169) pointed out, leisure has become increasingly important for Americans. Donovan und Halpern (2002: 25) show that British people who exercise regularly are more satisfied with their lives than those who do not. Similarly, regular gardening seems to make people feel better (Donovan und Halpern 2002: 25). Other leisure time activities that raise life satisfaction are social engagement and participation in religious activities (Helliwell 2003). It is however likely that at least some of these leisure activities influence well-being through their socialising aspects.

The EQLS contains very little information on leisure time activities. Involvement in voluntary organisations and contacts with friends or neighbours has already been mentioned above. Another activity is church attendance, which slightly increases subjective well-being. Moreover, people that are connected to the Internet are considerably more satisfied with their lives, although much of this effect is based on the socio-economic status of the typical Internet user.

Health

Being in good health has been an extremely important component of well-being in the objective approach (section 2.1). However, the subjective approach of well-being has found that objective health indicators only have a small impact on subjective well-being (Diener et al. 1999). The effects of bad health on life satisfaction seem to be only temporary (Brickman et al. 1978). However, self-reported, and hence subjective, health indicators have a strong effect on well-being (Helliwell 2003: 339)). The importance of such subjective health evaluation for well-being might be explained by personality (Okun und George 1984), and self-reported health might be therefore used to control for such personality differences.

Two subjective health indicators are available in the EQLS: the question of whether one has a long term illness or disability that limits one's activity, and health satisfaction. Both indicators are subjective in the sense that whether they think that they are limited in their activities, or whether they are satisfied with their health, depends on the respondents' subjective reference points. The strong gross effect of long term illness and health satisfaction mirror the known results that subjective health evaluations are important factors in subjective well-being. The coefficient for long term illness, however, changes its sign after controlling for health satisfaction. That is to say, out of two respondents with the same health satisfaction, the person with long term illness tends to be more satisfied with life than the person without. 


\section{$4 \quad$ Country differences in the production of well-being}

\subsection{Modernisation and the production of well-being}

The question of how inequalities are related to subjective well-being has until now been investigated in a global perspective: Which dimensions of inequality explain life satisfaction throughout Europe irrespective of country differences? A study of the available data shows something like a universal structure of well-being in Europe. However, the unexplained variance in the models as well as the fact that countries as such add explanatory value for life satisfaction outcomes suggest that country-specific patterns of life satisfaction compositions must exist. Following the idea of Ronald Inglehart (1977) one can expect that goods become less valuable when they can be taken for granted. This version of the modernisation theory suggests that the more developed a country is, the more important non-materialistic inequalities like "social integration" become for well-being compared to inequalities like "economic affluence". In what follows we will describe two empirical tests of this general idea.

\section{The relative importance of domain satisfactions}

In the European quality of life survey, the respondents were asked how satisfied they are with several domains, including health, education, standard of living, accommodation, family, and social life. In a sense, these so-called domain satisfactions can be seen as subjective evaluations of the major components of well-being. Following the idea raised above that goods become less valuable when they are taken for granted, it can be expected that more materialistic domains like education, standard of living, and accommodation should be more important in the poorer countries, while post-materialistic goods like family life and social life should be more important in the richer ones.

In order to explore this implication, we have estimated the effect of each domain satisfaction on general life satisfaction. Therefore we have estimated linear regression models of life satisfaction for each country and each domain satisfaction separately. ${ }^{1}$ The figure 4.1 shows whether these regression coefficients co-vary in the expected way with the economic affluence of countries. ${ }^{2}$ The results support the expectation that post-materialistic goods are more important in the more affluent countries. In poorer countries, i.e. in countries with low levels of GDP per capita, the effect of satisfaction with standard of living is clearly higher than in the more affluent countries. The same can be observed with regard to the effect of education, although less pronounced. At the same time, satisfaction with family and social life becomes more important in the richer countries. The effects

1 Gender, age, age-squared, income, employment status, and marital status were used as control variables.

2 Coefficients of Luxembourg have not been plotted in figure 6 because of Luxembourg's outstanding values for GDP per capita. 


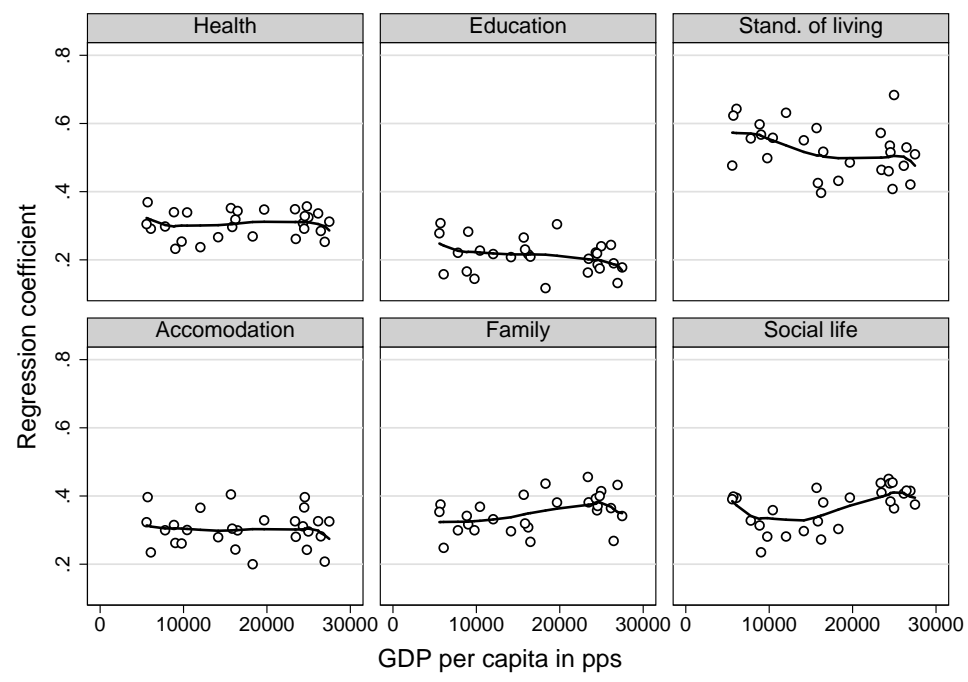

Figure 4.1: Country specific effects of domain satisfactions on well-being by GDP per capita

of satisfaction with health and accommodation do not interact with a country's economic prosperity.

This illustrative example can be confirmed by a more formal statistical analysis. We have set up a random intercept multi-level model, where we have used data from all countries together and treated countries as the first level variable. The models included GDP per capita and interaction terms between GDP and each domain satisfactions, one at a time. It turns out that the coefficients are significantly positive for the interactions of GDP with the two post-materialistic domains, while they were significantly negative for the interactions of GDP with the two materialistic domains education and standard of living. Hence, the higher the GDP, the more important satisfaction with family and social life becomes for well-being. At the same time, the importance of satisfaction with standard of living and education decreases.

\section{The relative importance of materialistic and non-materialistic goods}

Up to now we have used subjective indicators to show that the materialistic components tend to be of smaller value for life satisfaction outcomes in the more affluent countries. In the following, we present a corresponding analysis based on more objective indicators for similar domains. The analysis basically uses variants of the regression models presented in table 3.1, but this time we calculate them for each country separately. Like before we record regression coefficients of interest and analyse whether they vary systematically in size depending on a country's economic affluence. More specifically we look at the following contrasts: ${ }^{3}$

3 We have not used an indicator for health because it is unclear whether the available indicators can be regarded as "objective". All models included gender, age, age-squared, employment status, income, and education as control variables. For the effect of "contacts with friends and neighbours" we also included 
- Unemployment vs. employment as an indicator for the domain employment

- High vs. low formal education as an indicator for education

- Highest income quartile vs. lowest income quartile

- No problems with accommodation vs. at least two specific problems as an indicator for housing.

- Married vs. not married as an indicator for the family domain

- Regular contacts with friends and neighbours vs. not having those contacts for the domain sociability.

Again, we expect high influences of post-materialistic goods like family and sociability in the more affluent countries, while we suppose the materialistic goals to have a stronger impact in the less affluent countries. Figure 4.2 shows the results. ${ }^{4}$ Overall the data shown in figure 4.2 support the idea of a lower value of materialistic goods in more affluent countries. However, the results are not as clear cut as they were in the analysis using subjective domain satisfactions. Income obviously loses some of its explanatory power for wellbeing in the more affluent countries, while being married is becoming more important. The slight decline visible in the graph for contacts with friends and neighbours is contrary to expectation. However, this decline is insignificant in a random-intercept regression model similar to those described in the last section; thus, we do not regard this declining effect as evidence against the post-materialism hypothesis. All other effects show a more or less unsystematic connection with a country's affluence and can therefore not be taken as supporting evidence for the post-materialism hypothesis.

\subsection{The relative and absolute value of money}

Do desires have to be fulfilled in a relative or in an absolute sense? In other words, is it enough to posses a desired good, or do I need more of it than others have? Such questions are especially debated among economists, who investigate the relative and absolute income effects from the perspective of "utility". Duesenberry stressed the high importance of relative income for individual consumption and savings behaviour as early as 1949 . Easterlin (1974) explained the puzzling result that economic growth has not increased people's happiness with what has become known as the "comparison income" or "relative utility" effect (Easterlin 1995, 2001, 2005). He argues that raising the level of an individual's income above the income of other comparable people is more important for people's utility function than its absolute level. Increasing the income of all will therefore merely raise the aspiration levels instead of individual happiness. In a similar vein Kahnemann und Tversky (1979) define a value function over gains and losses with respect to some

marital status as control variable.

4 Coefficients of Luxembourg have not been plotted in figure 7 because of Luxembourg's outstanding values for GDP per capita. 


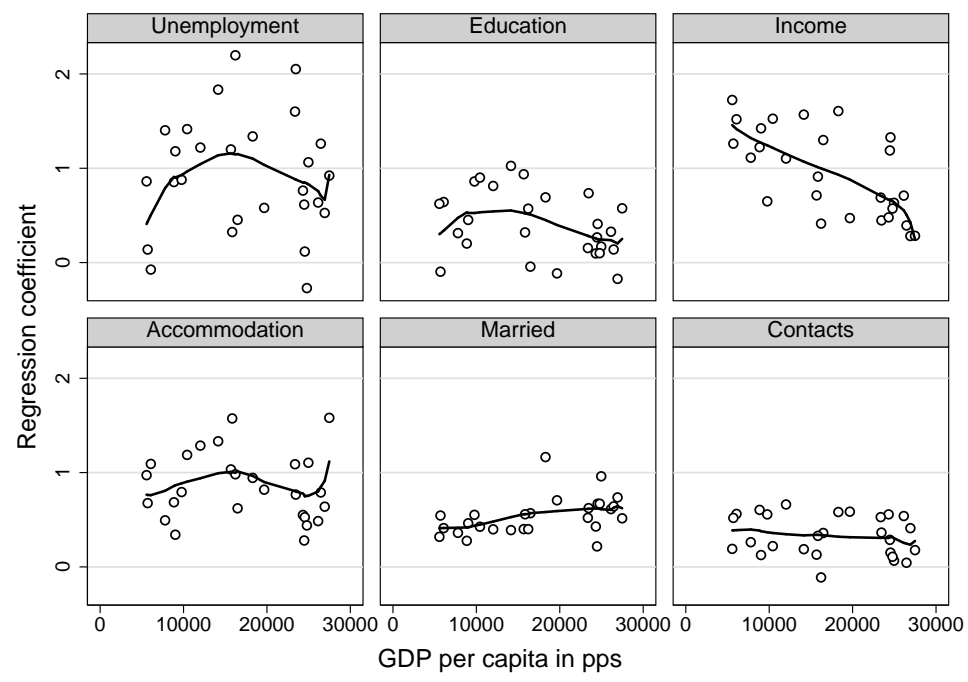

Figure 4.2: Country specific effects of dimensions of inequality on well-being by GDP per capita

natural reference point, and hence relative to this reference point. This idea of a "comparison income" has inspired a number of studies to compare the relative and absolute income effect (McBride 2001; Stutzer 2004; Ferrer-i-Carbonell 2005; Kohler 2007). Most of these studies stress the importance of relative income.

The subjective approach of the study of well-being can be fruitfully related to the debate about absolute vs. relative, especially when used in a comparative way. This section illustrates this with two examples that highlight the importance of the absolute income effect.

\section{Relative income and absolute deprivation}

One way to disentangle the relative and absolute effects of income is to set up different measures for relative and absolute income. An obvious measure for relative income is a categorisation of income into country specific quartiles. People in the upper quartile in poor countries can therefore be regarded as relatively rich - even if they are poor compared with persons from rich countries. Likewise, people in the lowest quartile in rich countries are relatively poor, even if they have an income that would qualify them as rich in a poor society.

Now for the measure of absolute income: In the EQLS, respondents were asked whether they could afford a lists of goods: keeping their home adequately warm, one week's holiday per year, replacing worn out furniture, a meal with meat once a week, new clothes, having friends or relatives for a drink once a month, a car, a home computer and a washing machine. We have defined people to be severely disadvantaged when they lacked three or more items in this list because of financial shortcomings. It is possible - and in fact even quite likely - that relatively poor persons in rich societies are not poor by the standards of 


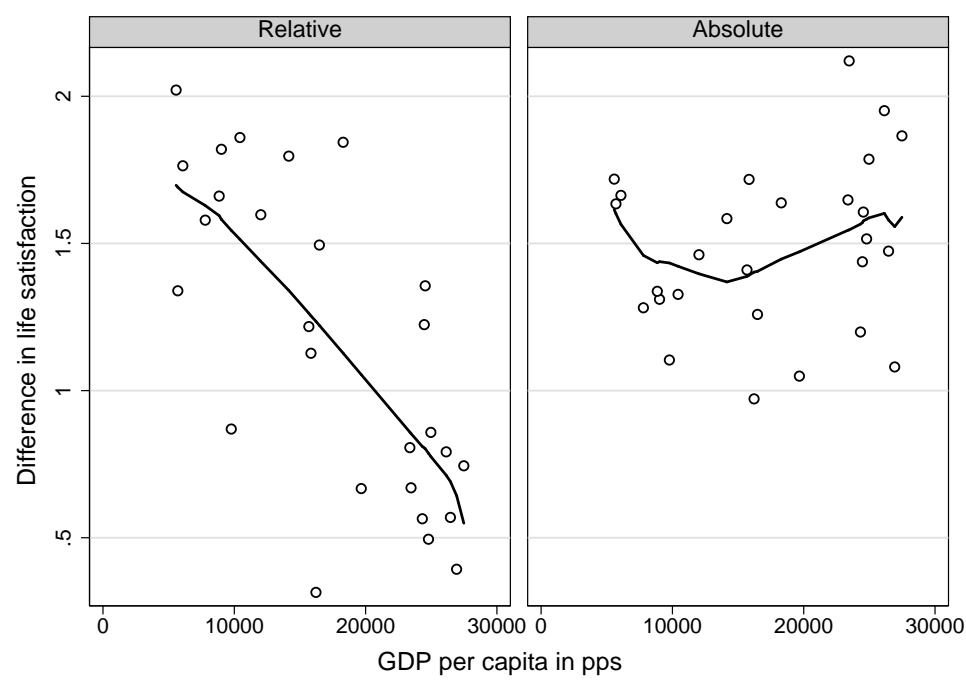

Figure 4.3: Country specific influence of relative income and absolute deprivation on life satisfaction by GDP per capita

this measure. Moreover, it is possible (and again not unlikely) that someone who is relatively rich in a poor country lacks more than three items anyway. Hence such a measure can be considered as a measure of absolute deprivation.

In figure 4.3 we have calculated the country specific differences of the average life satisfaction of the relatively rich and the relatively poor (graph on the left), and of the absolute rich and absolute poor (graph on the right). The higher the difference, the higher is the respective income effect.

First, note that it is a general pattern that life satisfaction is distributed according to the individual's income position. People in the top income quartile are more satisfied than people in the bottom income quartile in every country. Likewise, people who are not absolutely deprived have a higher life satisfaction than people who are absolutely deprived. However the difference between the relatively rich and the relatively poor tends to be far more pronounced in the poor countries than in the richer ones. With regard to absolute deprivation, the picture is remarkably different. Leaving the three poorest countries aside (Turkey, Bulgaria and Rumania), the difference in life satisfaction between people who cannot afford basic goods and people with higher incomes is much stronger in the more prosperous countries than in the poorer ones.

Putting both together, one might say that income, in general, is less important in rich societies, but being absolutely poor in a rich country is worse than being absolutely poor in a poor country. Several explanations can be offered for this striking result. One explanation would be that in poor countries, being absolutely poor is much more common and hence less stigmatising. Another, related explanation would be that being absolutely poor in poor societies is somehow buffered by social networks, or by a subsistence economy. 
How relative is absolute? The internationalisation of reference points

Do people need a specific amount of income to be satisfied, or do they strive for more income than people comparable to them? This question is not as clearly stated as it seems at first glance. Obviously, a "relatively" rich person in a poor society might be considered as poor by the standards of a rich society, and one is therefore tempted to regard this ideal typical person as relatively rich but absolutely poor. However, this classification rests on the usage of the co-nationals as the reference point for the definition of the relative income position. If one had used the joint population of the rich and poor countries as reference point for the definition of the relative income position, the person would have been not only absolutely, but also relatively poor. The absolute and relative income position would be indistinguishable then.

The selection of the reference point tends to be somewhat arbitrary. In the European definition of income poverty, individuals are regarded as poor if they earn much less than the country average. Hence, co-nationals are used as a reference-point for this definition of income poverty. However, other reference points are sensible as well. Ferrer-i-Carbonell (2005), for example, uses co-nationals with the same age as reference points, and defines individuals to be relatively poor if they earn less than the average of their birth cohort. Fahey (2007) argues towards the use of a common EU-threshold for the definition of poverty; his work can be understood as a plea for using the Europeans as a reference group. Obviously, the larger the group from which the reference point is derived, the less distinguishable relative income and absolute income gets. If the reference point were derived from the entire world population, absolute and relative income positions would be indistinguishable. In other words, what is often called an absolute income effect can be translated into a relative income effect - relative to a reference point derived from a population that goes beyond the national realm.

How do we know which reference point is the right one? In a recent publication Delhey und Kohler (2006) have demonstrated one way to answer this question. They show that the way people compare their own living conditions with the living conditions in other countries affect their subjective well-being. The lower individuals assess their own living conditions relative to those in foreign countries, the less content people are with their lives. This holds true for such different populations as the Germans, Hungarians and Turks, and was more recently also verified for all European countries Delhey und Kohler (2008). A further key result of the study was that upward comparisons matter more than downward comparisons. If people feel personally deprived, relative to other countries, they are less satisfied with their lives. Conversely, knowing themselves to be better off than those abroad only makes people a little more content.

Let us back-translate these results to the issue of relative and absolute income effects. To be in a relatively good position compared to one's co-nationals is often not enough to produce high subjective well-being. People also strive to achieve relatively good positions compared with people in other countries. One might want to call this an "absolute income effect" ; however it is probably more correct to say that the people with whom we compare ourselves are not only co-nationals. 

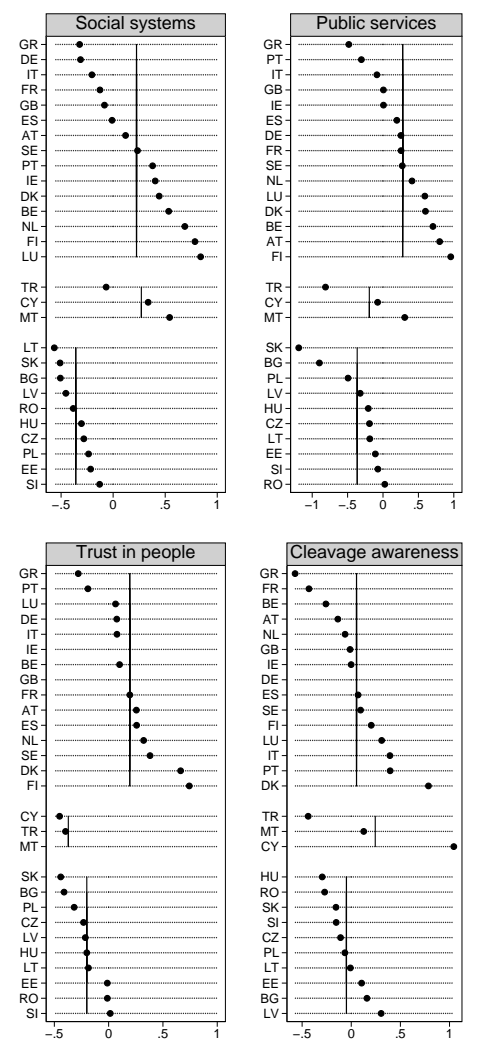

Figure 4.4: Average subjective evaluation of the quality of society by country

\subsection{Quality of society and its impact on well-being}

In the previous sections we have repeatedly analysed what role individually attained goods - either materialistic or not materialistic ones - play in the production of well-being. Political and cultural circumstances as a provider of life chances are severely neglected in this debate. The potential role of societal surroundings has been pointed out by Amatyra Sen (1993, 2000), when he emphasises "capabilities" as an important factor in understanding social inequality. In his view, political and institutional settings play an important role in limiting the ability of individuals to take advantage of certain life chances. In his eyes not only are the goods that individuals possess important for well-being, but also the possibilities a society offers for their production, availability and usage.

The empirical evaluation of the impact of political and societal circumstances on wellbeing is, however, problematic. Some studies deal with general information about a country's economic prosperity, and about its governance performance of welfare policy characteristics in order to establish guidelines to compare one country with another (Clark 2003; Inglehart und Klingemann 2000; Frey und Stutzer 2000; Helliwell 2003; Hofstede 2001). However, options and self-realisation as aspects of capabilities are not necessarily objective features of a society. Certain societies might offer a good chance of earning a high income, but restrict chances of leading a satisfying social life. What is considered 
as a "good" society also depends on its' citizens desires. Another operationalisation for freedom or limitations to act might therefore be the respondents' subjective evaluations of the quality of a society (Böhnke 2005): How people evaluate welfare state institutions and public services, whether they trust other people, or if they perceive many conflicts around them indicates worries and insecurities that might be negatively interrelated with personal well-being. Such a subjective measure of the quality of a society can be constructed on the basis of EQLS data. Figure 4.4 shows results for four different dimensions of (subjective) quality of society. The upper left graph shows how people evaluate the quality of the social benefit system and state pension system in their country, whereby high values reflect high quality in this branch of the society. The graph indicates that the social system is rated much lower by people from the former communist countries (FC) than from the traditional market economies. Basically, no transformation country has values above zero, which is the European average. A similar result also arises if one looks at two of the other dimensions of the subjective quality of society. The quality of public services (i.e. health services, educational system, public transport, social services, and state pension system) and trust in other people are both much lower in the former communist countries than in the old European member states. It is only in the awareness of cleavages between groups like young and old, men and women, rich and poor, managers and workers, and between ethnic groups, that the differentiation between former communist countries and old European member states is not that large; the strongest tensions between groups are seen by people from Greece, France and Turkey, while people from Denmark and Cyprus see few tensions between population groups.

The four subjective dimensions of quality of life can be considered as yet another component of well-being under the objective approach of well-being. However, under the subjective approach the question arises of whether the quality of the society really affects subjective well-being independently of other life domains such as access to material resources. Figure 4.5 shows country specific regression coefficients for the influence of the quality of society on subjective well-being (controlling for gender, age, income, employment status, and education). The results are quite clear-cut. All regression coefficients are positive, meaning that the better people evaluate the quality of their society, the higher is their individual well-being. How living conditions are embedded, and which opportunities and life chances people are provided with, obviously counts considerably towards life satisfaction. Although material shortcomings and perceptions of society are interrelated and people living in poverty are likely to evaluate their society more critically than others, these two different dimensions determine life satisfaction independently of each other noticeably throughout Europe. The important message is that fighting poverty and social disadvantage is not enough to increase subjective well-being.

The second result shown in figure 4.5 is also clear cut. The quality of society impacts far more on life satisfaction in the former communist countries than in the old European member states. More generally, there is a correlation between the overall level of prosperity in a country and the importance the quality of society has for the subjective well-being of the people. The lower the GDP per capita in a country is and, one might conclude, the weaker the social security net is, the more decisive is the perceived quality of the society to explain life satisfaction outcomes. Despite single deviations, this is the overall tendency 


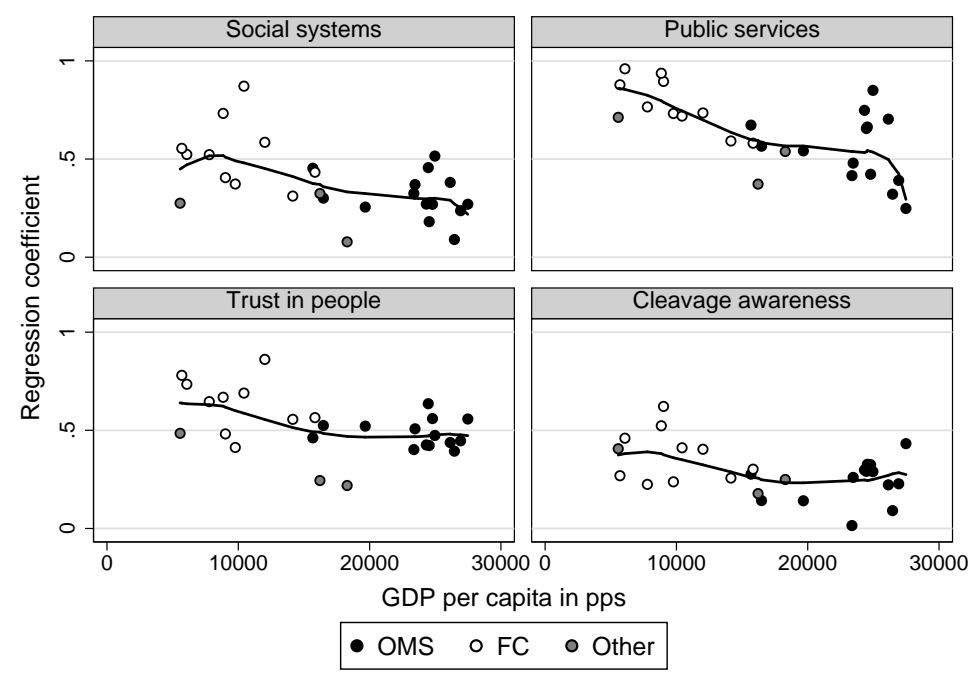

Figure 4.5: Country specific effects of perceived quality of society by GDP per capita

the graphical display suggests. All in all, the findings clearly demonstrate the influence societal circumstances have on individual well-being. 


\section{Summary}

We need a comprehensive approach in order to be able to understand well-being in Europe. The aim of this entry was to give an impression of how controversial the issue of wellbeing is scientifically, and how different the approaches to study well-being are. Furthermore, the results show how heterogeneous the distribution of various facets of well-being across Europe is, and revealed the important dimensions of inequality. First, we focused on well-being in terms of objective dimensions such as income, education, employment etc. and their distribution. Scandinavian and continental European countries perform quite well in several dimensions, while the former communist countries tend to have lower values. However, lots of variation and heterogeneity question this clear cut picture. With regard to family integration and solidaristic values, Southern and Eastern Europe perform much better than the North. High between-country variance is also the dominant impression when we deal with life satisfaction and happiness outcomes, although the sharp distinction between old European member states (high subjective well-being) and former communist countries (low subjective well-being) is remarkable. Furthermore, we asked about the determinants of subjective well-being as a proxy for well-being. Income, housing quality and integration in the labour market are important providers of well-being. But values other than materialistic ones also count; on the contrary, family and social network integration as well as health count as universal mechanisms which increase subjective well-being. Moreover, country specific analysis showed that family life and social contacts are more important for life satisfaction in countries where the general standard of living is high and material shortcomings are not dominating the daily routine. Finally, we would like to emphasise the role of political and social settings as important prevailing circumstances that shape life chances. The quality of a society, measured as the perception of conflicts, trust in people and the evaluation of social and public services, impacts strongly on life satisfaction outcomes; this is especially obvious in the transformation countries. The political circumstances in which someone experiences a decent life or miserable living conditions matter a lot: Societal surroundings turn out to be an influential domain for individual well-being. 


\section{Bibliography}

Alber, J., Anderson, R., Delhey, J., Domansky, H., Fahey, T., Keck, W., Maitre, B., Nauenburg, R., Olagnero, M., Ostrowska, A., Saraceno, C., Whelan, C. (2004): Quality of Life in Europe. First Results of a New Pan-European Survey. Luxembourg: Office for Official Publications of the European Communities.

Alber, J., Fahey, T. (2004): Perceptions of living conditions in an enlarged Europe. Luxembourg: European Foundation for the Improvement of Living and Working Conditions, Office for Official Publications of the European Communities (http://www.eurofound.eu.int/publications/ef03113en.pdf).

Alber, J., Fahey, T., Saraceno, C., Hg. (2008): Handbook of Quality of Life in the Enlarged European Union.. London: Routledge.

Alber, J., Kohler, U. (2004): Health and Care in an Enlarged Europe. Luxembourg: Office for Official Publications of the European Communities.

Allardt, E. (1993): Having, Loving, Being: An alternative to the Swedish Model of Welfare Research. In Nussbaum, M., Sen, A., Hg., The Quality of Life, Oxford: Oxford University Press, S. 88-94.

Andrews, F. M., Robinson, J. P. (1991): Measures of Subjective Well-Being. In Robinson, J. P., Shaver, P. R., Wrightsman, L. S., Hg., Measures of Personlity and Social Psychological Attitudes, San Diego: Academic Press, S. 61-114.

Argyle, M. (1999): Causes and Correlates of Happiness. In Kahnemann, D., Diener, E., Schwarz, N., Hg., Well-Being: The Foundations of Hedonic Psychology, New York: Russell Sage, S. 353-373.

Arvey, R. D., Bouchard, T. J., Segal, N., Abraham, L. M. (1989): Job Satisfaction: Environmental and Genetic Components. Journal of Applied Psychology, 74(2), 187-192.

Atkinson, T., Cantillon, B., Marlier, E., Nolan, B. (2002): Social Indicators. The EU and Social Inclusion. Oxford u. New York: Oxford University Press.

Becker, G. (1974): A theory of Social Interactions. Journal of Political Economy, 82(6), 1063-1093.

Blanchflower, D. G., Oswald, A. J. (2004): Well-being over time in Britain and the USA. Journal of Public Economics, 88, 1359-1386.

Böhnke, P. (2004): Perceptions of social integration and exclusion in an enlarged Europe, http://www.eurofound.eu.int/publications/EF0435EN.pdf.

Böhnke, P. (2005): First European Quality of Life Survey: Life Satisfaction, Happiness and Sense of Belonging. Luxembourg: Office for Official Publications of the European Communities.

Böhnke, P. (2006): Einkommensarm, aber beziehungsreich. In Alber, J., Merkel, W., Hg., Europas Osterweiterung: Das Ende der Vertiefung?, Berlin: Edition Sigma, S. 107-134.

Brickman, P., Campbell, D. T. (1971): Hedonic Relativism and Planning the Good Society. In Appley, M. H., Hg., Adaptation Level Theory: A Symposium, New York: Academic Press, S. 287-304.

Brickman, P., Coates, D., Janoff-Bulman, R. (1978): Lottery Winners and Accident Victims: Is Happiness Relative? Journal of Personality and Social Psychology, 36(8), 917-927.

Burns, L. S., Grebler, L. (1986): The Future of Housing Markets. A New Appraisal. London, New 
York: Plenum.

Campbell, A. (1981): The Sense of Well-Being in America. New York: McGraw-Hill.

Campbell, A., Converse, P. E., Rodgers, W. L. (1976): The quality of American life. Perceptions, evaluations, and satisfactions. New York: Russel Sage Foundation.

Clark, A. E. (1998): What Makes a Good Job? Evidence from OECD Countries, oECD, Labour Market and Social Policy, Occasional Papers Nr. 34.

Clark, A. E. (2003): Unemployment as a Social Norm: Psychological Evidence from Panel Data. Journal of Labor Economics, 21, 323-351.

Clark, A. E., Georgellis, Y., Sanfey, P. (2001): Scarring: The Psychological Impact of Past Unemployment. Economica, 68(270), 221-241.

Clark, A. E., Oswald, A. J. (1994): Unhapppiness and Unemployment. Economic Journal, 104(424), 648-659.

Clark, A. E., Oswald, A. J. (1996): Satisfaction and comparison income. Journal of Public Economics, 61(3), 359-381.

Costa, P. T., McCrae, R. R. (1988): Personality in Adulthood; A Six-Year Longitudinal Study of SelfReports and Spous Ratings on the NEO Personality Inventory. Journal of Personality and Social Psychology, 54(5), 853-863.

Davidson, R. J., Marshall, J. R., Tomarken, A. J., Henriques, J. B. (2000): While a Phobic Waits: Regional Brain Electrical and Autonomic Activity in Social Phobics During Anticipation of Public Speaking. Biological Psychiatry, 47(2), 85-95.

Delhey, J. (2004): Life Satisfaction in the Enlarged Europe. Luxembourg: European Foundation for the Improvement of Living and Working Conditions, Office for Official Publications of the European Communities (http://www.eurofound.eu.int/publications/EF0437EN.pdf).

Delhey, J., Kohler, U. (2006): From Nationally Bounded to Pan-European Inequalities? On the Importance of Foreign Countries as Reference Groups. European Sociological Review, 22(2), $125-140$.

Delhey, J., Kohler, U. (2008): Where We Stand in Europe. National Quality of Life, EU-average, and Personal Life Satisfaction. In Alber, J., Fahey, T., Saraceno, C., Hg., Handbook of Quality of Life in the Enlarged European Union, London: Routledge.

Dew, M. A., Bromet, E. J., Penkower, L. (1992): Mental Health Effects of Job Loss in Women. Psychological Medicine, 22(3), 751-764.

Di Tella, R., MacCulloch, R. J., Oswald, A. J. (2001): Preferences over Inflation and Unemployment: Evidence from Surveys of Happiness. American Economic Review, 91(1), 335-341.

Diener, E. (1984): Subjective Well-Being. Psychological Bulletin, 95(3), 542-575.

Diener, E., Suh, E. (1997): Measuring Quality of Life: Economic, Social, and subjective indicators. Social Indicators Research, 40(1-2), 189-216.

Diener, E., Suh, E., Lucas, R., Smith, H. (1999): Subjective Well-Being: Three Decades of Progress. Psycholgocial Bulletin, 125, 276-302.

Domanski, H., Alber, J. (2006): Paradoxes of Housing in the Enlarged Europe. In Alber, J., Merkel, W., Hg., Europas Osterweiterung: Das Ende der Vertiefung?, WZB Jahrbuch 2005, Berlin: Edition Sigma, S. 85-106.

Donovan, N., Halpern, D. (2002): Life Satisfaction: the State of Knowledge and Implications for Government, http://www.strategy.gov.uk/downloads/seminars/ls/paper.pdf. 
Duesenberry, J. S. (1949): Income, Savings and the Theory of Consumer Behavior. Cambridge: Harvard University Press.

Easterlin, R. A. (1974): Does economic growth improve the human lot? Some empirical evidence. In David, P. A., Reder, M. W., Hg., Nations and households in economic growth: Essays in honour of Moses Abramowitz, New York and London: Academic Press, S. 89-125.

Easterlin, R. A. (1995): Will Raising the Incomes of All Increase the Happiness of All? Journal of Economic Behavior and Organization, 27(1), 35-48.

Easterlin, R. A. (2001): Income and Happiness: Towards a Unified Theory. Economic Journal, 111(473), 465-484.

Easterlin, R. A. (2005): Feeding the Illusion of Growth and Happiness: a Reply to Hagerty and Veenhoven. Social Indicators Research, 74, 426-443.

Ehrhardt, J. J., Saris, W. E., Veenhoven, R. (2000): Stability of Life-Satisfaction over Time. Journal of Happiness Studies, 1(2), 177-205.

Erikson, R. (1993): Descriptions of Inequality: The Swedish Approach to Welfare Research. In Nussbaum, M., Sen, A., Hg., The Quality of Life, Oxford: Clarendon Press, S. 67-87.

Erikson, R., Goldthorpe, J. H. (1992): The Constant Flux: a Study of Class Mobility in Industrial Societies. Oxford: Clarendon Press.

Fahey, T. (2007): The Case for an EU-wide Measure of Poverty. European Sociological Review, 23(1), 35-47.

Fahey, T., Nolan, B., Whelan, C. T. (2003): Monitoring Quality of Life in Europe. Luxembourg: Office for Official Publications of the European Communities.

Fahey, T., Smyth, E. (2004): Do Subjecitve Indicators Measure Welfare? Evidence from 33 European societies. European Societies, 6(1), 5-27.

Feather, N. T. (1990): The Psychological Impact of Unemployment. New York: Springer.

Fernández-Dols, J.-M., Ruiz-Belda, M.-A. (1990): Are Smiles a Sign of Happiness? Gold Medal Winners at the Olympic Games. Journal of Personality and Social Psychology, 69(6), 11131119.

Ferrer-i-Carbonell, A. (2005): Income and Well-being: An Empirical Analysis of the Comparison Income Effect. Journal of Public Economics, 89, 997-1019.

Firebaugh, G., Tach, L. (2005): Relative income and happiness: are Americans on a hedonic treadmill?, http://www.sociology.psu.edu/faculty/documents/hedonictreadmill-latest_000.pdf.

Fordyce, M. A. (1988): A Review of Research on Happiness Measures: A Sixty Second Index of Happiness and Mental Health. Social Indicators Research, 20, 355-81.

Frederick, S., Loewenstein, G. (1999): Hedonic Adaptation. In Kahnemann, D., Diener, E., Schwarz, N., Hg., Well-Being: The Foundations of Hedonic Psychology, New York: Russell Sage Foundations, S. 302-329.

Frey, B. S., Stutzer, A. (2000): Happiness, Economy and Institutions. Economic Journal, 110(446), 918-938.

Frey, B. S., Stutzer, A. (2002): What can economists learn from happiness research? Journal of Economic Literature, 40(2), 402-435.

Gabriel, K. (1971): The Biplot Graphic Display of Matrices with Application to Principal Component Analysis. Biometrika, 58(3), 453-467.

Gardner, J., Oswald, A. J. (2001): Does Money Buy Happiness? A Longitudinal Study Using Data 
on Windfalls, http://ideas.repec.org/p/ecj/ac2002/81.html.

Goldsmith, A., Veum, J. R., Darity, W. J. (1996): The Impact of Labor Force History on Self-Esteem and its Component Parts, Anxiety, Alienation and Depression. Journal of Economic Psychology, 17(2), 183-220.

Goldthorpe, J. H. (1982): On the Service Class, its Formation and Future. In Giddens, A., MacKenzie, G., Hg., Classes and the Division of Labour. Essays in Honour of Ilya Neustadt., Cambridge: Cambridge University Presss, S. 162-185.

Graetz, B. (1993): Health Consequences of employment and Unemployment: Longitudinal Evidence for Young Men and Women. Social Science and Medicine, 36(6), 715-724.

Graham, C., Pettinato, S. (2001): Happiness, Markets and Democracy: Latin America in Comparative Perspective. Journal of Happiness Studies, 2(3), 237-268.

Hagerty, M., Veenhoven, R. (2003): Wealth and happiness revisited-growing national income does go with greater happiness. Social Indicators Research, 64, 1-27.

Halpern, D. (2005): Social Capital. Cambridge: Polity Press.

Hamer, D. H. (1996): The Heritability of Happiness. Nature Genetics, 14(2), 125-126.

Heady, B., Wearing, A. (1991): Subjective Well-Being: A Stocks and Flows Framework. In Strack, F., Argyle, M., Schwarz, N., Hg., Subjective Well-Being: An Interdisciplanary Perspective, Oxford: Pergamon Press, S. 7-26.

Helliwell, J. F. (2001): Social Capital, the Economy and Well-Being. In Banting, K., Sharpe, A., StHilaire, F., Hg., The Longest Decade: Canada in the 1990s, Bd. 1 von The Review of Economic Performance and Social Progress, Montreal: Centre for the Study of Living Standards, Institute for Research on Public Policy.

Helliwell, J. F. (2003): How's life? Combining individual and national variables to explain subjective well-being. Economic Modelling, 20, 331-360.

Helson, H. (1964): Adaptation-Level Theory: An Experimental ans Systematic Approach to Behavior. New York: Harper and Row.

Herzog, A., Rodgers, W. L., Woodworth, J. (1982): Subjective Well-Being Among different Age Groups.. Ann Arbor: Institiute for Social Research.

Hofstede, G. (2001): Culture's Consequences. Comparing Values, Behaviors, Institutions and Organizations Across Nations. Thousand Oaks, London, New Delhi: Sage.

Inglehart, R. (1977): The Silent Revolution . Changing Values and Political Styles Among Western Publics.. Princeton: Princeton University Press.

Inglehart, R. (1990): Culture shift in advanced industrial society. Princeton: Princeton University Press.

Inglehart, R., Klingemann, H.-D. (2000): Genes, culture, democracy, and happiness. In Diener, E., Suh, E., Hg., Culture and Subjective Well-being, Cambrige: MIT press, S. 165-183.

Inglehart, R., Rabier, J.-R. (1986): Aspirations adapt to situations - but why ar the Belgians so much happier than the French? In Andrews, F. M., Hg., Research on the Quality of Life, Ann Arbor: ICPSR, S. 1-56.

Irwin, F. (1944): The Realism of Expectations. Psychological Review, 51, 120-126.

Kahnemann, D., Tversky, A. (1979): Prospect Theory: An Analysis of Decision under Risk. Econometrica, 47(2), 263-291.

Kiel, K. A., Mieszkowski, P. (1990): An Examination of Systemic Differences in the Appreciation of 
Individual Housing Units. Journal of Real Estate Research, 5, 301-318.

Kohler, U. (2007): Containers, Europeanisation and individualisation: empirical implications of general decriptions of society. In Scherer, S., Pollack, R., Otte, G., Gangl, M., Hg., From Origin to Destination. Trends and Mechanisms in Social Stratification Research, Frankfurt a. M., New York.: Campus, S. 292-319.

Kohler, U., Luniak, M. (2005): Data inspection using biplots. Stata Journal, 5(2), 208-223.

Koivumaa, H. H., Honkanen, H. V., Heikkilae, K., Kaprio, J., Koskenvuo, M. (2001): Life Satisfaction and Suicide: A 20-Year Follow-up Study. American Journal of Psychiatry, 158(3), 433-39.

Lane, R. A. (1998): The Joyless Market Economy. In Avner, B.-N., Putterman, L., Hg., Economics, Values and Organization, New Haven, London: Yale University Press, S. 461-488.

Lane, R. A. (2000): The Loss of Happiness in Marked Democracies. New Haven, London: Yale University Press.

Larsen, R. J., Fredrickson, B. L. (1999): Measurement Issues in Emotion Research. In Kahnemann, D., Diener, E., Schwarz, N., Hg., Well-Being: The Foundations of Hedonic Psychology, New York: Russell Sage Foundations, S. 40-60.

Layard, R. (2005): Happiness. Lessons from a New Science. Harmondsworth: Penguin Press.

Lepper, H. (1998): Use of Other-Reports to Validate Subjective Well-Being Measures. Social Indicators Research, 44(3), 367-379.

Lykken, D., Tellegen, A. (1996): Happiness is a Stochastic Phenomenon. Psychological Science, 7(3), 186-189.

Marks, N., Gary N. Fleming (1999): Influences and Consequences of Well-being among Australian Young People: 1980-1995. Social Indicators Research, 46(3), 301-23.

McBride, M. (2001): Relative-income effets on subjective well-being in the cross-section. Journal of Economic Behavior \& Organization, 45, 251-278.

Michalos, A. C. (1991): Global Report on Student Well-Being. Volume 1: Life Satisfaction and Happiness. New York: Springer.

Mooser, J. (1983): Auflösung der proletarischen Milieus. Klassenbindung und Individualisierung in der Arbeiterschaft vom Kaiserreich bis in die Bundesrepublik Deutschland. Soziale Welt, 34, 270-306.

Neumark, D., Postlewaite, A. (1998): Relative Income Concerns and the Rise in married Women's Employment. Journal of Public Economy, 70(1), 157-183.

Ng, Y.-K. (1996): Happiness Surveys: Some Comparability Issues and an. Exploratory Survey Based on Just Perceivable Increments. Social Indicators Research, 38, 1-27.

Noll, H.-H., Hg. (1997): Sozialberichterstattung in Deutschland.. Weinheim: Juventa.

Okun, M. A., George, L. (1984): Physician and Self-Ratings of Health, Neuroticism and Subjective Well-Being Among Men and Women. Personality Individual Differences, 5, 533-540.

Otte, G. (2004): Sozialstrukturanalyse mit Lebensstilen. Wiesbaden: VS Verlag.

Parducci, A. (1995): Happiness, Pleasure, and Judgment: The Contextual Theory and Its Applications. Hillsdale,: Erlbaum.

Robine, J., Jagger, C., Euro-REVES Group (2003): Creating a Coherent Set of Indicators to Monitor Health Across Europe: The Euro-REVES 2 Project. European Journal for Public Health, 13(Suppl. 1), 6-14. 
Sandvik, E., Diener, E., Seidlitz, L. (1993): Subjective Well-Being: The Convergence and Stability of Self-Report and Non-Self-Reported Measures. Journal of Personality, 61(3), 317-342.

Schwarz, N., Strack, F. (1999): Reports of subjective well-being: judgemental processes and their methodological implications. In Kahnemann, D., Diener, E., Schwarz, N., Hg., Well-being: the foundations of hedonic psychology, New York: Sage, S. 353-373.

Sen, A. (1993): Capability and Well-Being. In Nussbaum, M., Sen, A., Hg., The Quality of Life, Oxford: Clarendon, S. 30-53.

Sen, A. (2000): Social Exclusion: Concept, Application and Scrutiny. Manila: Office of Environment and Social Development, Asian Development Bank.

Smith, A. D. (1995): Nations and Nationalism in the Global Era. Cambridge: Polity Press.

Spellerberg, A. (1995): Lebensstile in Ost- und Westdeutschland, Glatzer, W. and Noll, H.-H. (Ed.): Getrennt vereint. Lebensverhältnisse in Deutschland seit der Wiedervereinigung (Soziale Indikatoren XVI-II. Konzepte und Forschungsansätze. Sektion Soziale Indikatoren in der. In Glatzer, W., Noll, H.-H., Hg., Getrennt vereint. Lebensverhältnisse in Deutschland seit der Wiedervereinigung, Sozial Indidatoren XVI-II, Frankfurt a. M/New York: Campus.

Stutzer, A. (2004): The Role of Income Aspirations in Individual Happiness. Journal of Economic Behavior \& Organization, 54, 89-109.

Veenhoven, R. (1993): Happiness in Nations. Subjective Appreciation of Life in 56 Nations 19461992. Rotterdam: Erasmus University.

Veroff, J., Douvan, E., Kulka, R. A. (1981): The Inner American. A Self Portrait from 1957 to 1976. New York: Basic Books.

Vogel, J. (2002): Strategies and traditions in Swedish social reporting: a 30-year experience. Social Indicators Research, 58, 1-3.

Warr, P. (1999): Well-Being and the Workplace. In Kahnemann, D., Diener, E., Schwarz, N., Hg., Well-Being: The Foundations of Hedonic Psychology, New York: Russell Sage Foundations, S. 392-412.

Winkelmann, L., Winkelmann, R. (1998): Why are the Unemployed so Unhappy? Evidence from Panel Data. Economica, 65(257), 1-15.

Wippler, R. (1990): Cultural Resources and Participation in High Culture. In Hechter, M., Opp, K.D., Hechter, M., Hg., Social Institutions. Their Emergence, Maintenance and Effects, Berlin/New York: De Gruyter, S. 187-204.

Zapf, W. (1984): Individuelle Wohlfahrt: Lebensbedingungen und wahrgenommene Lebensqualität. In Glatzer, W., Zapf, W., Hg., Lebensqualität in der Bundesrepublick Deutschland. Objektive Lebensbedingungen und subjektives Wohlbefinden, Frankfurt a. M. u. New York: Campus, S. 13-26. 
The Research Area "Education, Work, and Life Changes" comprises the Research Units "Labour Market Policy and Employment", "Inequality and Social Integration" and "Skill Formation and Labor Markets", the Research Groups "Public Health" and "Education and Transitions into the Labour Market", the Research Professorships "Demographic Development, Social Change, and Social Capital" and "Social and Political Theory", and the Emmy Noether Junior Research Group "Love', Work, Recognition - Recognition and Inequality in Dual-Career Couples".

\section{Research Unit Inequality and Social Integration}

\section{Discussion Papers 2008}

Petra Böhnke, Ulrich Kohler Well-being and Inequality Order No.: SP I 2008 - 201

\section{Discussion Papers 2007}

Richard Rose

Evaluating Democratic Governance: A Bottom Up Approach to European Union Enlargement

Order No.: SP | $2007-201$

Petra Böhnke

Poverty and Social Integration in the Enlarged Europe

Order No.: SP | $2007-202$

Petra Böhnke

Policy or Privacy - What Matters Most for Individual Well-Being?

Order No.: SP | $2007-203$

Marco Albertini, Chiara Saraceno

Contact between adult children and their divorced parents: Italy in a comparative perspective

Order No.: SP | 2007 - 204

Jens Alber

Where Turkey stands in Europe and why it should be admitted to the EU Order No.: SP | $2007-205$

\section{Discussion Papers 2006}

Stein Ringen

Reflections on Inequality and Equality

Order No.: SP I 2006 - 201

\section{Discussion Papers 2005}

Ricarda Nauenburg

Globalisierung und rechtspopulistische Wahlerfolge

Order No.: SP | 2005 - 201

Eckhard Priller, Jana Sommerfeld Wer spendet in Deutschland? Eine sozialstrukturelle Analyse

Order No.: SP | 2005-202

Jan Delhey

A trade-off between enlargement and integration? An analysis of trust between EU nationalities

Order No.: SP I 2005 - 203

Jan Delhey, Urlich Kohler

From Nationally Bounded to PanEuropean Inequalities? On the Importance of Foreign Countries as Reference Groups

Order No.: SP I $2005-204$

\section{Discussion Papers 2004}

Jan Delhey

European Social Integration.

From convergence of countries to transnational relations between people Order No.: SP | 2004 - 201 
Jan Delhey, Kenneth Newton

Social Trust: Global Pattern or Nordic

Exceptionalism?

Order No.: SP I 2004 - 202

Ulrich Kohler

Empirische Untersuchung zweier Individualisierungshypothesen mit Querschnittsdaten aus 28 Ländern

Order No.: SP I 2004 - 203

Discussion Papers 2003

Harold L. Wilensky

Postindustrialism and

Postmaterialism? A Critical View of the

"New Economy", the "Information

Age", the "High Tech Society", and All

That

Order No.: SP I 2003 - 201

Wilhelm Hinrichs

Ausländische Bevölkerungsgruppen in Deutschland. Integrationschancen 1985 und 2000

Order No.: SP | 2003 - 202 